\title{
Nitric oxide and plant mineral nutrition: current knowledge
}

\author{
Agustina Buet ${ }^{1,2}$, Andrea Galatro ${ }^{1}$, Facundo Ramos-Artuso ${ }^{1,2}$, Marcela Simontacchi ${ }^{1,2} *$
}

${ }^{1}$ Instituto de Fisiología Vegetal (INFIVE), CCT- La Plata, Consejo Nacional de Investigaciones Científicas y Técnicas (CONICET), Diagonal 113 n 495, La Plata (1900), Buenos Aires, Argentina.

${ }^{2}$ Facultad de Ciencias Agrarias y Forestales, Universidad Nacional de La Plata (UNLP), Argentina.

* Correspondence: marcelasimontacchi@agro.unlp.edu.ar

\section{Highlight}

This review describes the impact of nitric oxide over plant mineral nutrition focusing on nitrogen, phosphate, potassium and iron homeostasis. The mechanisms involved in nitric oxide action are also discussed.

(C) The Author(s) 2019. Published by Oxford University Press on behalf of the Society for Experimental Biology. All rights reserved. For permissions, please email: journals.permissions@oup.com 


\begin{abstract}
Plants under essential mineral deficiencies trigger signaling mechanisms involving common components. Among them, nitric oxide (NO) has been pointed out as a key participant in responses to changes in nutrient availability.

Usually, nutrient imbalances affect NO levels in specific plant tissues, caused by modifications in its synthesis or degradation rates. Changes in NO level affect plant morphology and/or trigger responses associated to nutrient homeostasis, mediated by its interaction with reactive oxygen species (ROS), phytohormones and through posttranslational modifications to proteins. NO-related events constitute an exciting field of research to understand how plants adapt and respond to conditions of nutrient shortage. This review summarizes the current knowledge describing NO as a component of the multiple processes related to plant performance under conditions of deficiency in mineral nutrients focusing on macronutrients such as nitrogen, phosphate, potassium and magnesium, as well as micronutrients like iron and zinc.
\end{abstract}

\title{
Key words
}

Iron, Mineral nutrition, Nitric oxide, Nitrogen, Nutrient deficiency, Phosphate, Potassium

\section{Abbreviations}

ABA, abscisic acid; cPTIO, 2-(4-carboxyphenyl)-4,4,5,5-tetramethylimidazoline-1-oxyl-3oxide; DAF-FM DA, 4-amino-5-methylamino-2',7'-difluorofluorescein diacetate; DEA/NONOate, diethylamine NONOate; DNIC, dinitrosyl-iron complexes; FIT, FER-like iron-deficiency-induced transcription factor; FRO, ferric reductase oxidase; GA, gibberellins; GSH, glutathione; GSNO, S-nitrosoglutathione; GSNOR, S-nitrosoglutathione reductase; IRT, iron regulated tranporter; L-NAME, N $\omega$-nitro-L-arginine methyl ester; MNIC, mononitrosyl-iron complexes; NO, nitric oxide; NR, nitrate reductase; NOS, nitric oxide synthase; nsHbs, non-symbiotic haemoglobins; PLP, pyridoxal 5'-phosphate; PTM, post-translational modifications; ROS, reactive oxygen species; SNO, S-nitrosothiols; SNP, sodium nitroprusside.

(C) The Author(s) 2019. Published by Oxford University Press on behalf of the Society for Experimental Biology. All rights reserved. For permissions, please email: journals.permissions@oup.com 


\section{Introduction}

Plants are sessile organisms being exposed to continuing changes in environmental conditions. To survive, they have developed highly flexible and finely balanced mechanisms that allow them to sense and acclimate to multiple biotic and abiotic stress situations, such as variable soil nutrient concentrations. Deficiencies in essential mineral nutrients (macro- and micronutrients) lead to plant disorders related to the specific function of each nutrient in plant life, and trigger signaling mechanisms sharing pathways involving common components. Among them, nitric oxide (NO) has been involved in abiotic stress acclimation responses, such as the low nutrient supply (Meng et al., 2012).

To act as a signal molecule, NO has to be synthesized in a specific tissue under certain conditions, to react with specific targets and eventually the signaling cascade will be turned off. NO is endogenously produced in plants, in different cellular and subcellular compartments, under physiological and stress conditions (Astier et al., 2018). Although much progress has been made related to the knowledge of possible sources of NO in plants, the complete scenery is still elusive (Jeandroz et al., 2016; Chamizo-Ampudia et al., 2017; Corpas and Barroso, 2017).

Endogenously synthesized or exogenously applied NO, exerts its biological function, at least in part, due to protein modifications through i) reaction with tyrosine residues leading to tyrosine nitration, ii) binding to the thiol group of cysteinyl residues in a reaction so-called S-nitrosation (also termed as S-nitrosylation), or iii) interacting with metalloproteins, leading to conformational changes (reviewed in Astier and Lindermayr, 2012; Jain and Bhatla, 2018; Kolbert et al., 2017). In addition, NO is involved in a broad spectrum of biochemical events through the interaction with hormones, reactive oxygen species (ROS), and calcium (Garcia-Mata et al., 2003; Freschi, 2013; Domingos et al., 2015).

Not only proteins but also low molecular weight thiols can undergo S-nitrosation. The most abundant low molecular weight nitrosothiol is S-nitrosoglutathione (GSNO) which, in turn, is considered to be a form of storage and long distance transport of NO (Begara-Morales et al., 2018). The enzyme GSNO reductase (GSNOR) mediates GSNO turnover, giving ammonium and glutathione disulphide as products. The activity and the physiological role of GSNOR in plant metabolism have been recently reviewed 
(Lindermayr, 2018). NO is also scavenged by non-symbiotic haemoglobins (nsHbs) through a $\mathrm{NAD}(\mathrm{P}) \mathrm{H}$ dependent mechanism (Perazzolli et al., 2004). The expression of nsHbs in higher plants is increased under stress conditions (reviewed in Perazzolli et al., 2006). Interestingly, nsHbs are also able to react with S-nitrosothiols (SNO) leading to denitrosation (Perazzolli et al., 2004).

To our knowledge, the first report suggesting a role for NO in plant mineral nutrition came from the response to exogenous NO supply in maize plants suffering from iron (Fe) deficiency (Graziano et al., 2002). Since then, extensive evidence supporting its participation in plant mineral nutrition disorders has been accumulated and reported for other essentials elements: nitrogen $(\mathrm{N})$, phosphate $(\mathrm{P})$, potassium $(\mathrm{K})$, zinc $(\mathrm{Zn})$, and magnesium $(\mathrm{Mg})$, among others.

NO levels have been reported as increased in different plant tissues following alterations in nutrient supply due to modifications in its synthesis or degradation rates. The NO-related events that follow the NO increase constitute an exciting field of research to understand how plants may adapt to environmental conditions of nutrient shortage. This review will focus on $\mathrm{NO}$ as a key component of the multiple processes related to plant performance under several mineral nutrient deficiency conditions.

\section{Nitric oxide affects nitrogen uptake and homeostasis}

Nitrogen $(\mathrm{N})$ is an essential macronutrient, a building block of biological molecules such as nucleotides, amino acids, and proteins, which is critical for plant growth and development, and as a consequence for crop yield (Wang et al., 2012; O'Brien et al., 2016). Nitrate $\left(\mathrm{NO}_{3}{ }^{-}\right)$and ammonium $\left(\mathrm{NH}_{4}{ }^{+}\right)$are preferred $\mathrm{N}$ forms taken up by land plants; however they can be found in a short supply in most ecosystems as well as in agricultural lands (O'Brien et al., 2016). In agricultural systems, crop production relies on the application of nitrogenous fertilizers, but a large fraction of the $\mathrm{N}$ is not absorbed by plants, being lost into the environment causing several environmental and pollution problems (O’Brien et al., 2016; Kant, 2018).

Nitrogen supply in soil can fluctuate, and the root is the site where nutrient perception and acquisition occurs through efficient sensing systems (Alvarez et al., 2012). Local signaling pathways involve sensors, signal transduction pathway components, and 
effectors such as transcription factors that trigger $\mathrm{N}$ responses. Less is known about the systemic $\mathrm{N}$ signaling pathways in plants. It requires root-shoot-root communication, and in addition to $\mathrm{NO}_{3}{ }^{-}$, other $\mathrm{N}$-metabolites may function as systemic signals. Additional systemic signals include phytohormones like cytokinins and auxins (Alvarez et al., 2012). Local and systemic regulatory pathways participate in the modulation of root architecture by $\mathrm{NO}_{3}{ }^{-}$, where locally concentrated $\mathrm{NO}_{3}{ }^{-}$promotes lateral root elongation, and on the contrary high $\mathrm{NO}_{3}{ }^{-}$applied to the whole root has an inhibitory effect on lateral root development (Zhang et al., 1999, Alvarez et al., 2012). Regarding the effect of $\mathrm{NO}_{3}{ }^{-}$supply on primary root growth, there have been observed some contradictory reports showing inhibition, stimulation or no effect whatsoever (reviewed by Trevisan et al., 2014). As NO has been involved in root growth modulation (Correa-Aragunde et al., 2004; 2006), and $\mathrm{NO}_{3}{ }^{-}$and $\mathrm{NO}$ are metabolically connected, the possibility that $\mathrm{NO}$ may participate in $\mathrm{NO}_{3}{ }^{-}$ mediated root growth has been explored (Trevisan et al., 2014). A role for NO production in root response to $\mathrm{NO}_{3}{ }^{-}$was postulated due to the observation of a coordinate spatiotemporal expression of nitrate reductase (NR) and nsHbs, involved in NO synthesis and scavenging, respectively. These findings suggested that they could play an important role during the early perception and signaling of $\mathrm{NO}_{3}{ }^{-}$in the rhizosphere (Trevisan et al., 2011). The involvement of $\mathrm{NR}$ and $\mathrm{NO}$ in root response to $\mathrm{NO}_{3}{ }^{-}$or $\mathrm{NO}_{3}{ }^{-} / \mathrm{NH}_{4}{ }^{+}$(partial nitrate nutrition) has been confirmed with the use of chemical detection of NO in situ, and interfering with its synthesis (tungstate) or scavenging (2-(4-carboxyphenyl)-4,4,5,5tetramethylimidazoline-1-oxyl-3-oxide, cPTIO) in maize and rice (Manoli et al., 2014; Sun et al., 2015). An increase in the NO content in the lateral root region and the root tip of a high-nitrate-response rice cultivar (Nanguang) growing under partial $\mathrm{NO}_{3}{ }^{-}$nutrition conditions $(14 \mathrm{~d})$ as compared to $\mathrm{NH}_{4}{ }^{+}$treatment was observed, as well as an improved $\mathrm{N}$ acquisition capacity through the modulation of lateral root initiation and the $\mathrm{N}$ uptake rate. NO accumulation resulted mainly from an NIA2-dependent NR source (Sun et al., 2015). In maize plants, an early response was observed when seedlings grown for $24 \mathrm{~h}$ without $\mathrm{NO}_{3}{ }^{-}$were re-supplied with $\mathrm{NO}_{3}{ }^{-}$. The $\mathrm{NO}_{3}{ }^{-}$supply caused an increase in DAF- FM DA (4amino-5-methylamino-2',7'-difluorofluorescein diacetate) fluorescence (corresponding to NO detection) in the first minutes after treatment that was mainly localized immediately above the meristematic apex, in the transition zone. NO was produced by NR as an early 
response to $\mathrm{NO}_{3}{ }^{-}$supply and the coordinated induction of nsHbs could finely regulate steady state NO level. This mechanism may be implicated in the modulation of the root elongation in response to $\mathrm{NO}_{3}^{-}$perception (Manoli et al., 2014). The preferential localization and the strong transcriptional responsiveness of both $\mathrm{NR}$ and nsHbs in the transition zone of the apex strengthened the hypothesis of a role for this root portion in translating the environmental stimuli in developmental response (Trevisan et al., 2014). Trevisan and co-workers (2015) employing transcriptome and proteome studies confirmed that the transition zone was critical in sensing $\mathrm{NO}_{3}{ }^{-}$, and the contribution of $\mathrm{NO}$ to the $\mathrm{NO}_{3}{ }^{-}$ -induced transcriptional response. However other $\mathrm{NO}_{3}{ }^{-}$-derived signals also seem to contribute to this pathway. In addition, phytohormones, as auxin, seem to belong to the network of events involved in the adaptation to $\mathrm{NO}_{3}{ }^{-}$fluctuations. Therefore, it would seem possible to influence the pattern of root growth as well as the uptake capacity under specific conditions of $\mathrm{N}$ supply by manipulating elements involved in NO signaling (Simontacchi et al., 2015).

Despite the differences between species and treatments, NO seems to be implicated in $\mathrm{NO}_{3}{ }^{-}$modulation of root system architecture in a series of events that imply local and systemic responses and a tight regulation of NO levels through its synthesis and scavenging or consumption. Future research in other higher plants will add information about the complex regulation mechanisms involved in $\mathrm{N}$ perception and uptake under fluctuating situations.

$\mathrm{N}$ assimilation and NO generation are closely connected. It has been described that not only the amount of $\mathrm{N}$ (Caro and Puntarulo, 1998; Jin et al., 2009) but also the form of $\mathrm{N}$ supply $\left(\mathrm{NO}_{3}{ }^{-}\right.$or/and $\mathrm{NH}_{4}{ }^{+}$) (Sun et al., 2015; Zhu CQ et al., 2016) impact on NO levels. In fact, nitrite $\left(\mathrm{NO}_{2}^{-}\right)$and arginine, both derived from $\mathrm{N}$ assimilation and metabolism are the main substrates for NO synthesis. However, plants may have optimized the use of $\mathrm{NO}_{2}{ }^{-}$ as a main source for NO (Jeandroz et al., 2016; Santolini et al., 2017). NR is a key enzyme in the $\mathrm{N}$ metabolism and a source of NO (Chamizo-Ampudia et al., 2017), and in turn its activity may be affected by NO levels (Table 1). Regarding the possible mechanisms implicated in the modulation of NR activity, the absence of changes in the protein content and the conduction of in vitro experiments employing enzyme extracts lead to the idea of that the regulatory effect of NO on NR activity occurs at post-translational level (Jin et al., 
2009; Du et al., 2008; Rosales et al., 2011). In addition, in tomato roots the positive effect of NO on NR activity obtained in roots fed under low nitrate was reversed after the removal of NO, whereas the inhibition of NR from roots fed under high nitrate was irreversible (Jin et al., 2009). Thus different mechanism could be operative under different situations depending on $\mathrm{N}$ supply that will require further investigation. However, nitrotyrosines were not detected in purified NR from wheat leaves, either from controls or NO-treated samples (Rosales et al., 2011). A recent analysis indicates the possible sites of S-nitrosation in the protein (Fu et al., 2018), showing that NR from different plant species can undergo this post-translational modification (PTM) in the presence of NO donors. The presence of NO could alter NR functionality and, as a consequence, N assimilation (Jin et al., 2009; Rosales et al., 2011). Recently Balotf et al. (2018) studied the expression and activity of some enzymes from $\mathrm{N}$ assimilation pathways in two Australian wheat cultivars, cv. Spitfire (high nitrogen use efficiency, NUE) and cv. Westonia (normal NUE), under different combinations and levels of nitrogen sources, and the NO donor SNP (sodium nitroprusside). SNP treatment affected the activity (Table 1) and the expression of NR, and other enzymes of nitrogen assimilation pathway, showing that NO may have an important role in transcriptional and post-transcriptional regulation of $\mathrm{N}$ assimilation pathway enzymes. The dependence of the effect on $\mathrm{N}$ concentrations may be a strategy of the plants to increase NUE, as inducible effects on assimilation enzymes were observed mainly at low N concentrations (Balotf et al., 2018). Thus, different NO donors, such as SNP, GSNO, and diethylamine NONOate (DEA/NONOate), and the NO scavenger cPTIO were utilized to study the effects of NO supply on the NR activity in different species, tissues, and under different experimental conditions as $\mathrm{N}$ sources and supply. As it is summarized in Table 1, $\mathrm{NO}$ affects NR activity in a way that depends on the $\mathrm{N}$ source and level (as $\mathrm{NO}_{3}{ }^{-}$ concentration in the growth medium), the level of NO (or GSNO) reached inside the cell, as well as the duration of treatment, tissues and the species and genotypes, which may lead to different responses. In Chlamydomonas reinhardtii (Sanz-Luque et al., 2013), unlike other systems (Du et al., 2008; Jin et al., 2009), NO did not inhibit NR activity in extracts, but it did so in living cells, indicating that a cellular component or cell structure is necessary for NO inhibition of NR activity (Sanz-Luque et al., 2013). An unquestionable role for NO in modulating NR activity may be proposed and it should ultimately affect $\mathrm{N}$ metabolism, as 
$\mathrm{NR}$ is believed to be the rate-limiting step in $\mathrm{NO}_{3}{ }^{-}$assimilation pathway in plants. To add more complexity to this scenario, known mammalian nitric oxide synthase (NOS) inhibitors and polyamine treatments have modified NR activity (Rosales et al., 2011; 2012), indicating that $\mathrm{NO}$ from other sources, not directly related with $\mathrm{NO}_{3}{ }^{-}$assimilation, can also modulate NR activity. Additionally, in noxl mutants, which display increased NO synthesis, a NR-independent $\mathrm{NO}$ overproduction decreased $\mathrm{NO}_{3}{ }^{-}$content in part by suppressing its transport, suggesting that a NR-independent NO production may contribute to $\mathrm{NO}_{3}{ }^{-}$homeostasis (Frungillo et al., 2014).

Furthermore, NO seems to modulate N uptake systems. Sanz-Luque and co-workers (2013) described for the algae (Chlamydomonas reinhardtii) the fast and reversible inhibition of high-affinity $\mathrm{NH}_{4}{ }^{+}$transporter (HAAT) and high-affinity $\mathrm{NO}_{3}{ }^{-}$and $\mathrm{NO}_{2}{ }^{-}$ transporter (HAN/NiT) by NO, suggesting a post-translational regulation. It was also demonstrated that $\mathrm{NO}$ and $\mathrm{SNO}$ can modulate $\mathrm{N}$ assimilation by inhibiting differently $\mathrm{NO}_{3}{ }^{-}$ uptake and reduction (Frungillo et al., 2014). Elevated NO and SNO levels induced a switch from high- to low-affinity $\mathrm{NO}_{3}{ }^{-}$transport. It has been proposed that GSNO inhibits $\mathrm{NO}_{3}{ }^{-}$uptake and reduction and NO inhibits GSNOR1, by S-nitrosation, preventing GSNO degradation. Inhibition of GSNOR1 may be necessary to amplify SNO signals as GSNO prolongs NO half-life through the formation of a more stable pool of NO, which can also regulate $\mathrm{NO}_{3}{ }^{-}$assimilation and finely tune $\mathrm{N}$ homeostasis (Frungillo et al., 2014).

Overall, the reactions and molecules involved in $\mathrm{N}$ assimilation and metabolism, as well as in the NO generation, in addition to their multiple interactions, feedback connections, and the specific variations in particular organisms propose a complex scenario (Fig. 1). Future research in this field especially with crop cultures will contribute to understand the role of this signaling molecule in $\mathrm{N}$ nutrition, including the possibility of improving $\mathrm{N}$ availability under scarcity by modulating endogenous NO levels.

\section{Nitric oxide participates in acclimation to phosphorus restriction}

Phosphorus (P) is a major essential nutrient. It acts as a structural component of nucleic acids and membranes, and it is also a key component of signal transduction and energy metabolism (Plaxton and Tran, 2011). Low P availability in soils imposes an important worldwide crop yield limitation, thus phosphoric rock-derived fertilizers are 
extensively used to cope with P scarcity in agricultural systems, making P a key hit in food safety and ambient sustainability (Beardsley, 2011). The chemical form suitable for plant root uptake $\left(\mathrm{H}_{2} \mathrm{PO}_{4}{ }^{-}\right)$is frequently found at low concentration in soil solution, below $10 \mu \mathrm{M}$ (Shen et al., 2011), while the major $\mathrm{P}$ stock correspond to chemical forms that are unavailable for plants (precipitated, adsorbed to soil particles and organic P) (Holford, 1997; Raghothama 1999; Vance et al., 2003).

Plants are able to sense low $\mathrm{P}$ availability in soil and activate a complex signaling network to trigger several morphological and physiological responses, including the improvement of mutualistic relationships, in order to cope with P scarcity (Chiou and Lin, 2011; López-Arredondo et al., 2014; Zhang et al., 2014). Plants respond to P starvation in a variety of ways that include the release of $\mathrm{P}$ from vacuole; changes in membrane composition, replacing phospholipids with galactolipids and sulpholipids (Lambers et al., 2012); and the redistribution of $\mathrm{P}$ to the young actively growing tissues (Baker et al., 2015). At root level, the exudation of protons, organic anions and acid phosphatases increases $\mathrm{P}$ availability in the soil solution (Gaume et al., 2001; Brinch-Pedersen et al., 2002; Shen et al., 2006). Remodelling the root system and increasing P-transport activity improve both soil exploration and P uptake by plants (Raghothama and Karthikeyan, 2005; Lambers et al., 2006; 2011; Baker et al., 2015).

NO participation in modulation of several plant $\mathrm{P}$ starvation responses has been recently reported for different plant species, affecting both physiological processes and morphological traits (Wang et al., 2010; Zhu et al., 2017) (Fig. 2). In white lupin (Lupinus albus), Wang and co-workers (2010) described physiological changes associated to citrate exudation by roots, and morphological changes related to cluster root generation, both caused by $\mathrm{P}$ starvation and modulated by NO. In maize (Zea mays), employing the NO donor, GSNO, we found that in P-starved plants, NO increases the acid phosphatase activity in root tissues, the uptake of $\mathrm{P}$ from nutrient solution, and the decrease of $\mathrm{pH}$ in the external medium (Ramos-Artuso et al., 2018). In rice (Oryza sativa), changes in the internal $\mathrm{P}$ reutilization from cell walls under $\mathrm{P}$ starvation, has been described as a NO mediated process (Zhu CQ et al., 2016), in which NO acts upstream of ethylene (Zhu et al., 2017). 
Under P starvation it was found an increase in root sensitivity to auxin, which may affect root system architecture (López-Bucio et al., 2002; Nacry et al., 2005; Bouain et al., 2016). It was also postulated that $P$ starvation results in increases or decreases in auxin accumulation at different parts of the root system (Nacry et al., 2005; Sánchez-Calderón et al., 2005). $\mathrm{H}^{+}$-ATPase activity increases under $\mathrm{P}$ deficiency (Shen et al., 2006), which leads to a higher $\mathrm{P}$ uptake capacity via an anion $/ \mathrm{H}^{+}$co-transport process (Ullrich-Eberius et al., 1984) lowering the rhizosphere $\mathrm{pH}$. Auxins seems to have a role in the increase of $\mathrm{H}^{+}$ATPase activity (Frías et al., 1996), then it is possible to speculate an interaction between $\mathrm{NO}$ and auxins in the modulation of $\mathrm{H}^{+}$-ATPase activity, since $\mathrm{NO}$ levels rise under $\mathrm{P}$ starvation in root tissues (Wang et al., 2010). According to this hypothesis, the addition of exogenous NO to Phragmites communis calluses produced a great increase in the activity and the expression of plasma membrane $\mathrm{H}^{+}$-ATPase (Zhao et al., 2004). However, it is worth to mention that there is a lack of experimental evidence for the interplay among NOauxin in plants suffering from $P$ deficiency.

The impact of $\mathrm{P}$ restriction on root architecture varies among plant species. In the case of Arabidopsis, a clear effect is the restriction of primary root growth (SánchezCalderón et al., 2005; Niu et al., 2013). One possible explanation for root length restrain is the antagonistic effect of NO with giberellins (GA) action. DELLA proteins act as inhibitors of plant growth, and the GA/GA receptor (GID1)/DELLA interaction stimulates its degradation through the proteasome, preventing DELLA-mediated growth inhibition (Harberd et al., 2009), and thus promoting growth. Experimental support for the cross-talk NO-DELLAs came from the work performed by Lozano-Juste and León (2011) in plant responses to light, where exogenous NO increased the levels of DELLA proteins. It has been observed that DELLAs exert a restriction on primary root growth (Jiang et al., 2007) and that NO exerts a similar effect (Fernández-Marcos et al., 2011) in a DELLAs partially dependent mode (Fernández-Marcos et al., 2012). In Arabidopsis, a complete frame for the convergence of $\mathrm{P}$ supply, $\mathrm{NO}$ and GA in the inhibition of primary root growth was reported (Wu et al., 2014), demonstrating that the inhibitory effect of NO and low P on primary root growth depends on the DELLA pathway.

Soybean leaves exposed to short-term P-restriction exhibited increased NO levels (Ramos-Artuso et al., 2019). Some hypothesis may be proposed regarding the source of 
NO involved under low $\mathrm{P}$ availability: i) an increase of NR activity through dephosphorylation (Lillo et al., 2004) that could lead to a higher NO generation (ChamizoAmpudia et al., 2017; Ramos-Artuso et al., 2019), ii) an enhanced activity of xanthine oxido-reductase (XOR) (Wang et al., 2010), and/or iii) a higher content of the substrates arginine and nitrate (Rabe and Lovatt, 1986). The importance of the NR pathway for NO production under $\mathrm{P}$ restricted conditions has been demonstrated (Royo et al., 2015). NO levels increased substantially in Arabidopsis wild type (WT) roots exposed to P restriction, but decreased in the roots of the nia mutant. Also, nia mutants were more sensitive to $\mathrm{P}$ deprivation than the WT plants indicating a role for NO in the adaptation to low $\mathrm{P}$. In addition, $\mathrm{P}$ restriction has profound effects on mitochondrial electron flow increasing the pathway involving alternative oxidase $(\mathrm{AOX})$ in a mechanism mediated by NO (Royo et al., 2015).

Taken into account the effects exerted by NO on internal $\mathrm{P}$ reutilization, the release organic acids, acid phosphatases activity, P-uptake capacity, and the acidification of the growing medium, together with those affecting root architecture, it can be concluded that several acclimation mechanisms involved in $\mathrm{P}$-acquisition under low $\mathrm{P}$ are positively influenced by NO, suggesting a critical role of this molecule during the acclimation to Pdeficiency. Further research is needed to reveal the precise NO signalling mechanisms being involved in $\mathrm{P}$ deficiency response in different plant species.

\section{Nitric oxide affects potassium homeostasis in plants}

Potassium $\left(\mathrm{K}^{+}\right)$, a major nutrient, is accumulated up to $10 \%$ of the dry mass, being the major inorganic cation in plant cells. Inside the cells, $\mathrm{K}^{+}$cooperates in the formation of membrane potential and maintenance of cytosolic $\mathrm{pH}$ homeostasis. It interacts with charges of nucleic acids and proteins, and also acts as a cofactor activating specific enzymes (Maathuis, 2009; Dreyer and Uozomi, 2011). Maintaining $\mathrm{K}^{+}$homeostasis enables plants to operate metabolic pathways, but also contributes to set the osmotic potential and thus the turgor required for structure, plant growth and movements including stomatal aperture. Recent evidence suggests that cytosolic $\mathrm{K}^{+}$homeostasis is important as a signal in growth and development under stress conditions, mainly in redirecting energy from metabolic reactions to defense responses (Shabala, 2017). In the soil solution, $\mathrm{K}^{+}$concentration may 
vary within a wide range which is usually about 2-4 orders of magnitude lower than the concentration within the plant. At sub-millimolar concentrations, $\mathrm{K}^{+}$is typically taken up from the solution bathing the roots through the activity of specific Shaker like potassium channels and by $\mathrm{K}^{+}$-starvation induced KT-HAK-KUP transporters, AKT1 and AtHAK5 respectively; but other entities could also contribute to this transport process. The subsequent movement of $\mathrm{K}^{+}$within the cells and among plant organs involves several additional transporters (Véry et al., 2014; Santa-María et al., 2018).

There are many ways in which $\mathrm{K}^{+}$nutrition could be affected by the presence of $\mathrm{NO}$, one of them is through the general effect of NO on root architecture, in addition to an specific effect over $\mathrm{K}^{+}$transport (Fig. 3). An important relationship between $\mathrm{K}^{+}$and NO came also from a particular cellular type, the stomata. Furthermore in the complex interaction between $\mathrm{NO}$ and $\mathrm{K}^{+}$, some phytohormones are likely to play a key role.

Arabidopsis plants exposed to $\mathrm{K}^{+}$restriction reduced total root length and increased the density of second order lateral roots with no alteration in the root:shoot ratio (Gruber et al., 2013), while the root:shoot ratio increased in two wheat cultivars upon long term $\mathrm{K}^{+}$ restriction (Moriconi et al., 2012). In tobacco plants, a low $\mathrm{K}^{+}$-susceptible cultivar significantly decreased total root length, root volume and the number of first order lateral roots when exposed to $\mathrm{K}^{+}$restriction, whereas root morphology was not affected in a tolerant one (Song et al., 2018). For the susceptible cultivar current evidence suggests that NO plays an important role in modulating the growth of first-order lateral roots. Interestingly, roots of this cultivar exhibited increased levels of $\mathrm{NO}$ after $\mathrm{K}^{+}$-restriction. Consistently, the addition of two NO donors (SNP and DEA/NONOate) acts in the same way inhibiting first order lateral roots. According to that, the addition of cPTIO, L-NAME

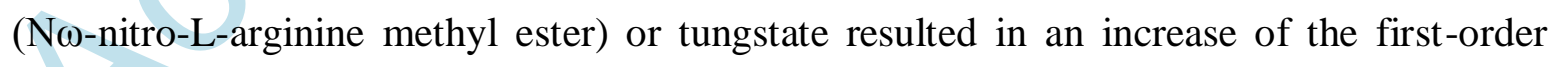
roots length (Song et al., 2018). Besides, indirect effects of NO on root elongation associated to defective $\mathrm{K}^{+}$-nutrition are likely to occur as observed in plants lacking AKT1 activity (aktl) for which root length proved to be hypersensitive to the NO donor SNP (Xia et al., 2014).

As $\mathrm{K}^{+}$plays major roles in plant function, the $\mathrm{K}^{+}$transport capacity is, not surprisingly, subjected to multiple regulations (Amtmann and Blatt, 2009; Santa-María et al., 2018). Xia and co-workers (2014), in the search of a connection between the changes in 
$\mathrm{K}^{+}$content and the altered levels of NO during salt stress, found that $\mathrm{NO}$ lowers $\mathrm{K}^{+}$channel AKT1 activity in Xenopus oocytes and protoplasts under conditions of adequate $\mathrm{K}^{+}$supply. As above mentioned, the AKT1 channel likely contributes to a major route for $\mathrm{K}^{+}$ absorption in Arabidopsis in most environments (Véry et al., 2014). The mechanism proposed by which NO exerts its negative effect on AKT1 does not involve a direct action of NO on the channel. Instead high NO levels increase the content of pyridoxal 5'phosphate (PLP), an active form of vitamin B6, which in turn inhibits the activity of AKT1 (Xia et al., 2014). Therefore $\mathrm{NO}$ mediates $\mathrm{K}^{+}$homeostasis by the negative regulation of $\mathrm{K}^{+}$ uptake via AKT1. It remains unknown whether or not a similar negative effect involves the other major player in $\mathrm{K}^{+}$uptake from diluted $\mathrm{K}^{+}$solutions, AtHAK5. It is interesting to note that recent work with the nialnia2 mutant, defective in NR activity, unveiled that leaf $\mathrm{K}^{+}$ content was impaired in those plants (Chen et al., 2016). While this result indirectly suggests that $\mathrm{NO}$ would be involved in the control of long-distance transport of $\mathrm{K}^{+}$, it could be also interpreted in terms of the reciprocal interaction between $\mathrm{K}^{+}$and $\mathrm{N}$ nutrition.

Another NO-mediated alteration in $\mathrm{K}^{+}$homeostasis resulted from the work with Arabidopsis roots treated with excess iron (Fe) (Zhang et al., 2018). In the root tips, the levels of NO increased as a consequence of exposure to toxic Fe concentrations (Arnaud et al., 2006), leading to growth arrest, which in part is related to NO-induced alteration in $\mathrm{K}^{+}$ homeostasis. In the search for the fluxes determining imbalanced $\mathrm{K}^{+}$homeostasis, the authors found a net loss of $\mathrm{K}^{+}$from apical root zones. $\mathrm{K}^{+}$efflux from roots is thought to be mediated by $\mathrm{K}^{+}$-selective channels, nonselective cation channels and annexins (reviewed in Demidchik et al., 2014). The observation that Fe-induced $\mathrm{K}^{+}$efflux currents are diminished by the presence of $\mathrm{Gd}^{3+}$, suggests that non-selective cation channels could be involved in the process studied. The addition of the NO donor SNP stimulates $\mathrm{K}^{+}$efflux, while that of the NO scavenger cPTIO reduces it, thus indicating that those currents are related with $\mathrm{NO}$ signaling. Furthermore, the authors obtained evidence that addition of PLP contributes to $\mathrm{K}^{+}$efflux. In the mechanism proposed by Zhang and coworkers (2018), NO-induces $\mathrm{K}^{+}$ loss by nonselective cation channels (NSCCs), via regulation of the levels of PLP, thus establishing a parallelism with the findings above mentioned for AKT1 regulation (Xia et al., 2014). The significant loss of $\mathrm{K}^{+}$induced by exposure to high Fe levels, could likely exert its detrimental effect on root elongation either by reducing cell turgor thus limiting 
cell expansion, by affecting metabolic processes or by eliciting a cell death process as found under stress conditions (Demidchik et al., 2010).

It is known that $\mathrm{NO}$ enhances plant tolerance to drought by affecting stomatal closure evoked by abscisic acid (ABA) (Garcia-Mata and Lamattina, 2003). In Vicia faba guard cells, NO promotes intracellular $\mathrm{Ca}^{2+}$ release and thus regulates $\mathrm{Ca}^{2+}$-sensitive $\mathrm{K}^{+}$ inward channels at the plasma membrane (Garcia-Mata et al., 2003). Later, a direct effect was proposed for NO locking down the outward-rectifying $\mathrm{K}^{+}$channels mediated by Snitrosation of cysteinyl residues in the ion channel protein (Sokolovski and Blatt, 2004). Rise in NO levels following ABA perception by guard cells is proposed to rely on the activity of NR, as it was previously suggested (Scuffi et al., 2014) and confirmed by the use of nialnia2 Arabidopsis mutant, lacking the two genes coding for NR (Chen et al., 2016). The double mutant showed reduced NO synthesis and lower leaf $\mathrm{K}^{+}$content, and stomata exhibited ABA insensitivity; however, they responded to exogenous NO addition. Alteration in $\mathrm{K}^{+}$homeostasis in plants with reduced NR activity correlates with a reduction in $K A T 2, A K T 2$ and $K C l$ transcripts, coding for channels involved in $\mathrm{K}^{+}$transport, as well as $G O R K$ transcripts coding for an outward rectifier $\mathrm{K}^{+}$-channel involved in $\mathrm{K}^{+}$efflux, and increases in the accumulation of transcripts coding for the inward rectifier $\mathrm{K}^{+}$channels KAT1 and AKT1. According to the model offered by the authors, in Arabidopsis guard cells, ABA-induced stomatal closure involves NO derived from NR activity, which contributes to inhibit inward currents mediated by the KAT1 and AKT1 $\mathrm{K}^{+}$channels through a $\mathrm{Ca}^{2+}$-dependent mechanism (Chen et al., 2016).

Overall, the available evidence suggests a major role for $\mathrm{NO}$ in modulating $\mathrm{K}^{+}$ accumulation in plants as well as the movements at cellular level (Fig. 3), which may be particularly relevant when plants face stress conditions.

\section{Nitric oxide is a central player in iron homeostasis in plants}

Iron $(\mathrm{Fe})$ is an essential micronutrient for plants. Given its redox properties, Fe acts as an important cofactor in enzymes and component in proteins. Fe containing proteins take part in the electron transfer chain of mitochondrion and chloroplasts and in the chlorophyll biosynthetic pathway; evidencing its importance for plant physiology. Despite being one of the most abundant elements on Earth's crust, plants are frequently exposed to Fe deficiency 
Due to its low bioavailability as a result of the poor solubility of Fe in the soil solution, (Ma and Ling, 2009). Fe deficiency causes symptoms in plants that severely affect growth and development. On the other hand, Fe overload and the presence of high Fe levels in tissues can lead to oxidative stress and damage owing to the generation of ROS through Fenton's reaction (Halliwell and Gutteridge, 1999). This situation is more likely to occur under waterlogging conditions (Nikolic and Pavlovic, 2018).

The mechanisms developed for higher plants to acquire Fe from soils could be classified into two strategies. Non-graminaceous plants have evolved Strategy I which consists in the induction of the activity of an $\mathrm{H}^{+}$-ATPase pump associated to the plasma membrane that acidifies the rhizosphere, a ferric reductase oxidase (FRO) that localizes at the plasma membrane and catalyzes the reduction of $\mathrm{Fe}^{3+}$ to $\mathrm{Fe}^{2+}$, and a $\mathrm{Fe}^{2+}$-transporter, so-called iron regulated transporter (IRT) (Kobayashi and Nishizawa, 2012). The expression of these genes is regulated by a FER/FER-like transcription factor (Lucena et al., 2006). Meanwhile graminaceous plants have adopted Strategy II which is based on the release of phytosiderophores to the rhizosphere to chelate $\mathrm{Fe}^{3+}$ and the activity of transporters that take $\mathrm{Fe}^{3+}$-phytosiderophore complexes into the root symplast, called yellow stripe (YS) and yellow stripe-like (YSL) (Kobayashi and Nishizawa, 2012). In some plant species, these two strategies coexist, such as the case of rice (Ishimaru et al., 2006). $\mathrm{NO}$ is involved in the regulation of both Fe-uptake strategies.

It has been evidenced that in tomato and Arabidopsis, Fe deficiency causes an increase in NO levels evaluated by the employment of DAF-FM DA . Endogenous NO, and also exogenous NO (released by GSNO), reverts chlorosis (Graziano et al., 2002), positively modulates the expression of FIT (FER-like Iron-deficiency-induced transcription factor, in Arabidopsis) or FER (in tomato), and consequently, FRO and IRT (Graziano and Lamattina, 2007; Chen et al., 2010). In tomato, NR dependent pathway is likely involved in NO synthesis, given that plants under Fe-restriction treated with tungstate (a known NR inhibitor) have not shown NO accumulation and nia mutants (which display a $20 \%$ of NR activity present in WT plants) have a weaker induction of Strategy I gene expression (Graziano and Lamattina, 2007). Meanwhile, it has been proposed that in Arabidopsis, NO generated under Fe deficiency comes mainly from both NR and arginine-dependent synthesis (Chen et al., 2010). In addition, assays with cPTIO, an NO scavenger, confirmed 
that NO induces the expression of FER and favours its stability by inhibiting its proteasomal degradation (Meiser et al., 2011).

The effect of NO on FER/FIT accumulation is paralleled by auxins and ethylene. The interplay between NO and auxins has been addressed early whereas ethylene has recently emerged as a new player in conjunction with NO in plant mineral nutrition (García et al., 2011). Chen and co-workers (2010) have proven that Fe deficiency triggers auxins accumulation that leads to a NO burst and the subsequent induction of FIT in Arabidopsis, while other works describe the involvement of ethylene in this response (Lucena et al., 2006; García et al., 2010). It has been evidenced by the assays performed in Arabidopsis and cucumber plants, using an ethylene precursor (1-aminocyclopropane-1-carboxylic acid), an inhibitor (silver thiosulphate), and an NO donor (GSNO) and scavenger (cPTIO), that Fe deficiency provokes NO accumulation that induces ethylene synthesis that, in turn, enhances NO levels (García et al., 2011). Thus ethylene would be the responsible for FIT induction. Taken these data together, we can speculate a model of low Fe responses (Fig. 4) in which low Fe levels may induce the increase in auxins that result in NO accumulation and the subsequent ethylene raise leads to FIT regulated Strategy I gene expression. However, it is worth mentioning that ethylene and NO are also able to modulate auxins activity (Stepanova et al., 2007; Terrile et al., 2012). It would be interesting to study this proposed model in the light of the availability of Arabidopsis mutants for auxins, ethylene and NO.

Research focused on NO role in $\mathrm{Fe}$ acquisition by graminaceous plants is less abundant than that focusing on plants using Strategy I. Increased NO levels were found in rice roots in response to Fe-deficiency, assessed by DAF-FM DA fluorescence (Sun et al., 2017; Zhu et al., 2018). Interestingly, Fe-deficient plants showed increased NR expression and activity, supporting a role in NO biosynthesis in this condition (Sun et al., 2017). Recently, it has been reported that rice plants grown under Fe-deficient supply in the presence of $\mathrm{NH}_{4}{ }^{+}$showed enhanced NO levels and have higher expression levels of the $\mathrm{Fe}$ transporters OsIRT1 (corresponding to Strategy I) and OsYSL15 (corresponding to Strategy II) than plants grown under Fe-deficient supply but in the presence of $\mathrm{NO}_{3}{ }^{-}$, suggesting that an oxidative NO synthesis pathway could be also operative (Zhu et al., 2018). The induced expression of the Fe transporters could be related to the differential NO 
accumulation suggesting a role for NO in Fe-deficiency responses in graminaceous plants, although, more studies are required to confirm this hypothesis. It has also been established that changes in root architecture in response to Fe deficiency are mediated by NO and auxins. NO acts downstream of auxins, similarly to that observed in Strategy I plants (Sun et al., 2017).

Several studies have highlighted the importance of shoot-root communication for inducing Fe-deficiency responses (Durrett et al., 2007; García et al., 2013; Chen et al., 2018). García and colleagues (2013) revealed that foliar Fe fertilization blocks Fedeficiency responses related to Fe-acquisition in different plant species and these results were confirmed in mutants expressing constitutively $\mathrm{Fe}$-acquisition genes. One relevant transporter involved in Fe loading into the phloem is Oligopeptide Transporter 3 (OPT3) that is able to transport Fe, likely in a chelated form. The exact nature of the signal molecule implicated in this regulation has not been described yet but, recently, it has been reported that this signal requires functional expression of OPT3 for repression of ethylene synthesis and GSNOR activity in Arabidopsis roots (García et al., 2018). It is hypothesized that under Fe-deficient conditions, this signal is not sent from shoots to roots, inducing ethylene synthesis and GSNOR activity in roots, suggesting that low GSNO levels are required for ethylene and NO accumulation, leading to Fe deficiency responses. In this regard, it is relevant to note that GSNO levels in cells regulate the extent of S-nitrosation (Begara-Morales et al., 2018). Even though García and co-workers (2018) did not determine NO and auxin levels, it could be suggested, considering all data, that at sufficient Fe supply, this iron signal could be repressing auxins in the proposed model.

As mentioned above, roots of Arabidopsis plants grown under Fe deficient conditions showed a low content of GSNO (Shanmugam et al., 2015; García et al. 2018). However, it is worth to mention that it has been evidenced an increase of glutathione (GSH) levels in these conditions (Shanmugam et al., 2015; García et al. 2018), and this increase could be required to trigger NO accumulation, as illustrated by the absence of DAF-FM fluorescence accumulation when plants were incubated with an inhibitor of GSH synthesis (buthionine sulfoximine) (Shanmugam et al., 2015). This piece of evidence adds more complexity to Strategy I response regulation and it would be interesting to thoroughly study 
GSH and NO interaction taking into account the Strategy I regulation by the phytohormones auxins and ethylene.

Moreover, NO also plays an important role in internal Fe homeostasis under Fesufficient and deficient supply. NO improves the internal availability of Fe (Graziano et al., 2002; Jasid et al., 2008; Simontacchi et al., 2012). This characteristic relies, at least in part, on the ability to form nitrosyl-Fe complexes. These complexes consist of one or two molecules of NO attached to low molecular weight thiol ligand and coordinated with an atom of Fe, resulting in mononitrosyl- or dinitrosyl Fe complexes (MNIC and DNIC, respectively), that contribute to the labile iron pool, the fraction readily bioavailable of total Fe (Simontacchi et al., 2012). Through the formation of this kind of complexes, Fe is kept in a redox safety and available form for plant metabolism (Jasid et al., 2008; Simontacchi et al., 2012).

On the other hand, NO has been described to mediate the accumulation of ferritin in response to $\mathrm{Fe}$ (Murgia et al., 2002) by triggering ubiquitinilation of ferritin repressor (Arnaud et al., 2006). Ferritins are ubiquitous proteins that storage Fe in a safely form, preventing Fenton reactions (Galatro and Puntarulo, 2007). More recently, it has been reported that NO leads to increased ferritin expression during senescence in Lotus japonicus nodules (Chungopast et al., 2017). Another protein relevant regarding $\mathrm{Fe}$ homeostasis is frataxin. This mitochondrial protein is involved in the assembly of Fe-S clusters. Arabidopsis frataxin knock-down plants displayed high Fe levels in mitochondria and plastids in roots, leading to oxidative damage (Busi et al., 2006). These plants showed increased NO that ameliorates oxidative stress either by inducing ferritin expression or by a direct antioxidant function (Martin et al., 2009). It would be interesting to explore the contribution of MNIC and DNIC formation to avoid high free Fe levels in these mutants.

Regarding the improvement of Fe availability, it could be pointed out a role for NO in Fe utilization efficiency. Reports evidencing a modulation of Fe remobilization by NO have been recently published. Putrescine induced NO accumulation in Arabidopsis triggers changes in cell-wall composition leading to Fe release from cell-walls and increasing $\mathrm{Fe}$ available levels (Zhu XF et al., 2016). Zhu and colleagues (2018) reached to the same conclusion in rice plants grown under Fe deficient supply but in the presence of $\mathrm{NH}_{4}{ }^{+}$. 
It would be interesting for future research to deepen on the knowledge about NO regulation of Fe acquisition in Strategy II plants, and to investigate the role of NO in the modulation of the mechanisms implicated in Fe use efficiency for improve crops growth under Fe deficient conditions.

\section{NO and other mineral nutrients homeostasis}

There are fewer studies regarding the interaction between NO and other mineral nutrient deficiencies like magnesium $(\mathrm{Mg})$ and zinc $(\mathrm{Zn})$. Here we summarized some of the current information regarding NO role under some responses to these mineral disorders.

In Arabidopsis plants exposed to Mg deficiency, root hair development is promoted, and using mutants with altered levels of $\mathrm{NO}$ and ethylene, the participation of both species was recently analyzed (Liu et al., 2017). Upon Mg deficiency, a burst of NO was observed, as well as an increase in ethylene production. Elongation and development of root hairs in plants exposed to $\mathrm{Mg}$ deficiency was impaired in the mutants nial,2 and noal (with lower NO levels) and ein2-5 and ein3-1 (ethylene-insensitive) (Liu et al., 2017). These findings were also confirmed by the use of a pharmacological approach, where the application of SNP to Mg sufficient wild type plants increased the length and density of root hairs, while the opposite effect was observed after the application of NO scavenger c-PTIO under $\mathrm{Mg}$ deficiency. In addition, the NOS inhibitor L-NAME and the NR inhibitor tungstate inhibited root hair development in $\mathrm{Mg}$ - deficient plants.

Plants can be exposed to excess or deficiency of $\mathrm{Zn}$, and as a micronutrient both conditions affect plant growth and development. Most of the reports involving NO and $\mathrm{Zn}$ interaction described increases in NO levels in response to high Zn (Xu et al., 2010; Duan et al., 2015; Feigl et al., 2016). However, there is a lack of knowledge about NO participation in plants exposed to $\mathrm{Zn}$ deficiency. It has been reported that the addition of a NO-donor (GSNO) during recovery experiments after $\mathrm{Zn}$-deprivation lead to a reduced net $\mathrm{Zn}$ uptake from a $2 \mu \mathrm{M} \mathrm{Zn}$ solution in wheat plants, suggesting that $\mathrm{NO}$ has the capacity to down-modulate the accumulation of $\mathrm{Zn}$ under conditions of adequate/high Zinc supply thus helping plants to prevent the rise of $\mathrm{Zn}$ within tissues (Buet et al., 2014). However, further studies are needed to disclose the specific effect of $\mathrm{NO}$ over $\mathrm{Zn}$ transport processes and on the transporters underlying them. 


\section{Mechanisms of NO participation in plant mineral nutrition}

It is evident from several reports that the increase in NO levels is a common event when plants are exposed to suboptimal amount of different elements, thus it could be considered as a general response to mineral imbalances (Fig. 5) (Wang et al., 2010; Buet and Simontacchi, 2015; Sun et al., 2015; Liu et al., 2017). NO may be produced in higher plants from a variety of enzymatic and non-enzymatic sources, that have been extensively reviewed (Moreau et al., 2010; Fröhlich and Durner, 2011; Gupta et al., 2011; Mur et al., 2013; Astier et al., 2018) and may contribute to increase NO under mineral deficiencies.

NO has a general effect in the regulation of root system architecture. It is known that plants facing mineral deficiencies adapt their root morphology, physiology and metabolism in order to explore the soil, modify the physical-chemistry properties of the rhizosphere and enhance nutrient uptake. Even though modifications in root system due to mineral scarcity largely depend on the nutrient availability and vary among plant species or cultivars (Kellermeier et al., 2013), NO can be considered a common component of some observed responses. NO also participates in the formation of root hair upon mineral nutrient restriction (Lombardo et al., 2006), enhancing nutrient acquisition by the increase in the surface area of roots.

A positive correlation seems to be operative between $\mathrm{NO}$ and ethylene, where NO stimulates ethylene synthesis and vice versa (Wang et al., 2009; García et al., 2011; Zhu et $a l ., 2017)$. Both NO and ethylene enhance auxin levels in roots exposed to $\mathrm{Mg}$ deficiency, likely affecting its transport (Liu et al., 2018). In turn, elevated auxin levels exert a positive feedback loop, being necessary for the increased NO and ethylene levels in Mg-deficient plants (Liu et al., 2018). It has also been shown the existence of a close interrelationship between DELLAs, a key effector in gibberellin signaling, and NO signaling in plant responses to P-deprivation (Wu et al., 2014). These findings pointed out the relevance of the complex interaction in which NO may influence phytohormone biosynthesis, catabolism, conjugation, transport, perception or transduction (Freschi, 2013). 
PTM of proteins impact plant performance under physiological and stress conditions (Domingos et al., 2015; Simontacchi et al., 2015; Begara-Morales et al., 2018). NO can react with superoxide anion to give peroxynitrite $\left(\mathrm{ONOO}^{-}\right)$, a highly reactive oxidant capable of adding a nitro group to the aromatic ring of tyrosine residues present in proteins. It is worth mentioning that despite being a result from a non-enzymatic reaction, nitrated proteins are present in low quantities under physiological conditions, representing only $1-2 \%$ of the total tyrosine pool (Radi 2004; Chaki et al., 2009; Lozano-Juste et al., 2011; Kolbert et al., 2017) and tend to increase under stress conditions (David et al., 2015; Feigl et al., 2016). In soybean leaves, chloroplast proteins seem to be a target of this PTM, in coincidence with a proposed site for NO generation (Galatro et al., 2013, Ramos-Artuso et al., 2019). In Brassica qualitative differences in protein nitration patterns were observed between plant species with differences in plant performance under $\mathrm{Zn}$ toxicity conditions (Feigl et al., 2016). However, under short term P-deprivation in soybean leaves, although NO levels were increased, tyrosine nitration was not drastically affected (Ramos-Artuso et al., 2019).

S-nitrosation is another PTM by which NO modulates protein activity through the attachment of a nitrosyl group to cysteinyl residues (Astier et al., 2011). S-nitrosation has emerged as a signal for plant growth and development processes and it has also been described that the level of S-nitrosation in proteins changes in response to abiotic stress (Yun et al., 2011; Ortega-Galisteo et al., 2012; Terrile et al., 2012; Albertos et al., 2015). The pattern of proteins showing this PTM was affected in mitochondria from plants exposed to $\mathrm{NaCl}$ (Camejo et al., 2013). Biological functions of $\mathrm{NO}$ in plants are partially mediated by S-nitrosation of transcription factors, and it was recently described that other important step in transcriptional control, the chromatin state, is also affected by NO (Mengel et al., 2017). The findings suggest that plant histone deacetylases might be targets of S-nitrosation or S-glutathionylation (incorporation of a glutathione molecule to a cysteinyl residue) resulting in the hyperacetylation of specific genes. This mechanism might operate facilitating the stress-induced transcription of genes. It has also been reported the modulation of a group of WRKY transcription factors, involved in abiotic stress tolerance, by NO (Imran et al., 2018). Most of the NO-responsive WRKY transcription 
factors have a cysteine or a tyrosine residue near to the WRKY domain, suggesting a mechanism of regulation by S-nitrosation or tyrosine nitration.

These common mechanisms help to explain the broad spectrum of NO actions that are put into play when plants are exposed to nutrient imbalances (Fig. 5), ranging from PTM in proteins, enzymes, transporters and transcription factors that contribute to perform some physiological responses, through the interaction with phytohormone action allowing to face with nutritional stress situations.

\section{Concluding remarks}

In light of the evidence regarding the role of NO in plant mineral nutrition presented here, it should be highlighted its involvement in some responses to low nutrient supply, including macro and micronutrients. In most of these responses, a strong interaction with hormones (mainly auxins and ethylene) has been evidenced. Also, changes associated with root morphology or to the expression of specific proteins involved in nutrient homeostasis (such as transport proteins involved in uptake and translocation), and redox control (such as antioxidants and proteins as ferritin involved in safe Fe storage) has been described. Some interactions may be mediated by NO PTM of regulatory and targets proteins and also by the promotion of gene expression. It would be interesting to deepen the studies that link proteomic changes with organelle specific ionome in plants under specific mineral nutrient imbalances.

The increase in NO levels triggered by the deficiency of a particular nutrient, also involves the regulation of the homeostasis of other nutrients as evidenced by the work of Meng and collaborators (2012). This evidence adds a greater complexity to the study of the responses modulated by NO under mineral nutrition, implying a regulatory network of plant ionome. The regulation of plant ionome by NO constitutes a field of study that remains largely unexplored and the advances in this area of research could lead to an integral knowledge about the regulation of plant mineral nutrition. In addition, there is a lack of knowledge, likely to due technical hitches, regarding NO signaling in local and systemic responses to microelement deficiencies.

From the studies performed employing NO donors, a caution note should be added regarding the use of SNP as the only NO donor in a high number of works analyzed. This 
widely used NO donor is a metal-NO complex that contains Fe and may release cyanide during the exposition. So assays employing other NO donors or scavengers are needed to strongly sustain the relationship between NO and the reported responses.

Different mechanisms could be involved in NO generation due to changes in mineral nutrition, where NR seems to have a critical role. The specific level of NO required to exert a particular function may be finely tuned by the molecules involved in its synthesis, consumption, or stabilization (such as endogenous GSNO and nitrosyl iron compounds) that would finally modulate (or trigger) the observed response. In this context, the potential use of NO donors (Marvasi 2017), as well as the possibility to elicit endogenous levels by modulating the sources and mechanisms involved in its generation/consumption, opens a great field of research in the search for a sustainable agriculture.

\section{Acknowledgments}

This work was supported by funds from Agencia Nacional de Promoción Científica y Tencnológica (ANPCyT) [PICT 2014-1887; PICT 2017-2492], Universidad de La Plata (A322). $\mathrm{AB}, \mathrm{AG}$, and $\mathrm{MS}$ are researchers from Consejo Nacional de Investigaciones Científicas y Técnicas (CONICET). FR-A thanks to CONICET for a fellowship. We are very grateful to Dr G.E. Santa-María for helpful comments and Alan Bausano for language corrections. 


\section{References}

Albertos P, Romero-Puertas MC, Tatematsu K, Mateos I, Sánchez-Vicente I, Nambara E, Lorenzo O. 2015. S-nitrosylation triggers ABI5 degradation to promote seed germination and seedling growth. Nature communications 6, 8669.

Alvarez JM, Vidal EA, Gutiérrez RA. 2012. Integration of local and systemic signaling pathways for plant $\mathrm{N}$ responses. Current Opinion in Plant Biology 15, 185-191.

Amtmann A, Blatt MR. 2009. Regulation of macronutrient transport. New Phytologist 181, 35-52.

Arnaud N, Murgia I, Boucherez J, Briat J-F, Cellier F, Gaymard F. 2006. An ironinduced nitric oxide burst precedes ubiquitin-dependent protein degradation for Arabidopsis AtFerl ferritin gene expression. Journal of Biological Chemistry 281, 2357923588.

Astier J, Gross I, Durner J. 2018. Nitric oxide production in plants: an update. Journal of Experimental Botany 69, 3401-3411.

Astier J, Lindermayr C. 2012. Nitric oxide-dependent posttranslational modification in plants: an update. International Journal of Molecular Sciences 13, 15193-15208.

Astier J, Rasul S, Koen E, Manzoor H, Besson-Bard A, Lamotte O, Jeandroz S, Durner J, Lindermayr C, Wendehenne D. 2011. S-nitrosylation: An emerging posttranslational protein modification in plants. Plant Science 181, 527-533.

Baker A, Ceasar SA, Palmer AJ, Paterson JB, Qi W, Muench SP, Baldwin SA. 2015. Replace, reuse, recycle: improving the sustainable use of phosphorus by plants. Journal of Experimental Botany 66, 3523-3540.

Balotf S, Islam S, Kavoosi G, Kholdebarin B, Juhasz A, Ma W. 2018. How exogenous nitric oxide regulates nitrogen assimilation in wheat seedlings under different nitrogen sources and levels. PLoS ONE 13, e0190269.

Beardsley TM. 2011. Peak phosphorus. BioScience 61,91-91.

Begara-Morales JC, Chaki M, Valderrama R, Sánchez-Calvo B, Mata-Pérez C, Padilla MN, Corpas FJ, Barroso JB. 2018. Nitric oxide buffering and conditional nitric oxide release in stress response. Journal of Experimental Botany 69, 3425-3438.

(C) The Author(s) 2019. Published by Oxford University Press on behalf of the Society for Experimental Biology. All rights reserved. For permissions, please email: journals.permissions@oup.com 
Bouain N, Doumas P, Rouached H. 2016. Recent advances in understanding the molecular mechanisms regulating the root system response to phosphate deficiency in Arabidopsis. Curr Genomics. 17, 308-4.

Brinch-Pedersen H, Sørensen LD, Holm PB. 2002. Engineering crop plants: getting a handle on phosphate. Trends in Plant Science 7, 118-125.

Buet A, Moriconi JI, Santa-María GE, Simontacchi M. 2014. An exogenous source of nitric oxide modulates zinc nutritional status in wheat plants. Plant Physiology and Biochemistry 83, 337-345.

Buet A, Simontacchi M. 2015. Nitric oxide and plant iron homeostasis. Annals of the New York Academy of Sciences 1340, 39-46.

Busi MV, Maliandi MV, Valdez H, Clemente M, Zabaleta EJ, Araya A, Gomez-Casati DF. 2006. Deficiency of Arabidopsis thaliana frataxin alters activity of mitochondrial Fe-S proteins and induces oxidative stress. The Plant Journal 48, 873-882.

Camejo D, Romero-Puertas MC, Rodríguez-Serrano M, Sandalio LM, Lázaro JJ, Jiménez A, Sevilla F. 2013. Salinity-induced changes in S-nitrosylation of pea mitochondrial proteins. Journal of Proteomics 79, 87-99.

Caro A, Puntarulo S. 1998. Nitric oxide decreases superoxide anion generation by microsomes from soybean embryonic axes. Physiologia Plantarum 104, 357-364.

Chaki M, Valderrama R, Fernández-Ocaña AM, et al. 2009. Protein targets of tyrosine nitration in sunflower (Helianthus annuus L.) hypocotyls. Journal of Experimental Botany 60, 4221-4234.

Chamizo-Ampudia A, Sanz-Luque E, Llamas Á, Galván A, Fernández E. 2017. Nitrate reductase regulates plant nitric oxide homeostasis. Trends in Plant Science 22, 163-174.

Chen L, Wang G, Chen P, Zhu H, Wang S, Ding Y. 2018. Shoot-root communication plays a key role in physiological alterations of rice (Oryza sativa) under iron deficiency. Frontiers in Plant Science 9, 757. doi:10.3389/fpls.2018.00757

Chen WW, Yang JL, Qin C, Jin CW, Mo JH, Ye T, Zheng SJ. 2010. Nitric oxide acts downstream of auxin to trigger root ferric-chelate reductase activity in response to iron deficiency in Arabidopsis. Plant Physiology 154, 810-819.

Chen ZH, Wang Y, Wang JW, Babla M, Zhao C, García-Mata C, Sani E, Differ C, Mak M, Hills A, Amtmann A, Blatt MR. 2016. Nitrate reductase mutation alters 
potassium nutrition as well as nitric oxide-mediated control of guard cell ion channels in Arabidopsis. New Phytologist 209, 1456-1469.

Chiou T, Lin S. 2011. Signaling network in sensing phosphate availability in plants. Annual Review of Plant Biology 62, 185-206.

Chow F, Pedersén M, Oliveira MC. 2013. Modulation of nitrate reductase activity by photosynthetic electron transport chain and nitric oxide balance in the red macroalga Gracilaria chilensis (Gracilariales, Rhodophyta). Journal of Applied Phycology 25, 18471853.

Chungopast S, Duangkhet M, Tajima S, Ma JF, Nomura M. 2017. Iron-induced nitric oxide leads to an increase in the expression of ferritin during the senescence of Lotus japonicus nodules. Journal of Plant Physiology 208, 40-46.

Corpas FJ, Barroso JB. 2017. Nitric oxide synthase-like activity in higher plants. Nitric Oxide 68, 5-6.

Correa-Aragunde N, Cejudo FJ, Lamattina L. 2015. Nitric oxide is required for the auxin-induced activation of NADPH-dependent thioredoxin reductase and protein denitrosylation during root growth responses in arabidopsis. Annals of Botany 116, 695702.

Correa-Aragunde N, Graziano M, Chevalier C, Lamattina L. 2006. Nitric oxide modulates the expression of cell cycle regulatory genes during lateral root formation in tomato. Journal of Experimental Botany 57, 581-588.

Correa-Aragunde N, Graziano M, Lamattina L. 2004. Nitric oxide plays a central role in determining lateral root development in tomato. Planta 218, 900-905.

David A, Yadav S, Baluška F, Bhatla SC. 2015. Nitric oxide accumulation and protein tyrosine nitration as a rapid and long distance signalling response to salt stress in sunflower seedlings. Nitric Oxide 50, 28-37.

Demidchik V, Cuin TA, Svistunenko D, Smith SJ, Miller AJ, Shabala S, Sokolik A, Yurin V. 2010. Arabidopsis root $\mathrm{K}^{+}$-efflux conductance activated by hydroxyl radicals: single-channel properties, genetic basis and involvement in stress-induced cell death. Journal of Cell Science, doi: 10.1242/jcs.064352

Demidchik V, Straltsova D, Medvedev SS, Pozhvanov GA, Sokolik A, Yurin V. 2014. Stress-induced electrolyte leakage: the role of $\mathrm{K}^{+}$-permeable channels and involvement in 
programmed cell death and metabolic adjustment. Journal of Experimental Botany $\mathbf{6 5}$, 1259-1270.

Domingos P, Prado AM, Wong A, Gehring C, Feijo JA. 2015. Nitric oxide: a multitasked signaling gas in plants. Molecular Plant 8, 506-520.

Dreyer I, Uozumi N. 2011. Potassium channels in plant cells. The FEBS Journal 278, 4293-4303.

Du S, Zhang Y, Lin X, Wang YUE, Tang C. 2008. Regulation of nitrate reductase by nitric oxide in Chinese cabbage pakchoi (Brassica chinensis L.). Plant, Cell \& Environment 31, 195-204.

Duan X, Li X, Ding F, Zhao J, Guo A, Zhang L, Yao J, Yang Y. 2015. Interaction of nitric oxide and reactive oxygen species and associated regulation of root growth in wheat seedlings under zinc stress. Ecotoxicology and Environmental Safety 113, 95-102.

Durrett TP, Gassmann W, Rogers EE. 2007. The FRD3-mediated efflux of citrate into the root vasculature is necessary for efficient iron translocation. Plant Physiology 144, 197205.

Feigl G, Kolbert Z, Lehotai N, Molnár Á, Ördög A, Bordé Á, Laskay G, Erdei L. 2016. Different zinc sensitivity of Brassica organs is accompanied by distinct responses in protein nitration level and pattern. Ecotoxicology and Environmental Safety 125, 141-152.

Fernández-Marcos M, Sanz L, Lewis DR, Muday GK, Lorenzo O. 2011. Nitric oxide causes root apical meristem defects and growth inhibition while reducing PIN-FORMED 1 (PIN1)-dependent acropetal auxin transport. Proceedings of the National Academy of Sciences 108, 18506-18511.

Fernández-Marcos M, Sanz L, Lorenzo O. 2012. Nitric oxide - An emerging regulator of cell elongation during primary root growth. Plant Signaling \& Behavior 7, 196-200.

Freschi L. 2013. Nitric oxide and phytohormone interactions: current status and perspectives. Frontiers in Plant Science 4, doi:10.3389/fpls.2013.00398

Frías I, Caldeira MT, Pérez-Castiñeira JR, Navarro-Aviñó JP, Culiañez-Maciá FA, Kuppinger O, Stransky H, Pagés M, Hager A, Serrano R. 1996. A major isoform of the maize plasma membrane $\mathrm{H}(+)$-ATPase: characterization and induction by auxin in coleoptiles. The Plant Cell 8, 1533-1544.

Fröhlich A, Durner J. 2011. The hunt for plant nitric oxide synthase (NOS): Is one really 
needed? Plant Science 181, 401-404.

Frungillo L, Skelly MJ, Loake GJ, Spoel SH, Salgado I. 2014. S-nitrosothiols regulate nitric oxide production and storage in plants through the nitrogen assimilation pathway. Nature Communications 5, doi:10.1038/ncomms6401

Fu Y-F, Zhang Z-W, Yuan S. 2018. Putative connections between nitrate reductase Snitrosylation and NO synthesis under pathogen attacks and abiotic stresses. Frontiers in Plant Science 9:474. doi: 10.3389/fpls.2018.00474

Galatro A, Puntarulo S. 2007. Mitochondrial ferritin in animals and plants. Frontiers in Bioscience 12, 1063-1071.

Galatro A, Puntarulo S, Guiamet JJ, Simontacchi M. 2013. Chloroplast functionality impacts on nitric oxide level in soybean cotyledons. Plant Physiology and Biochemistry, 66, 26-33.

García MJ, Corpas FJ, Lucena C, Alcántara E, Pérez-Vicente R, Zamarreño ÁM, Bacaicoa E, García-Mina JM, Bauer P, Romera FJ. 2018. A shoot Fe signaling pathway requiring the OPT3 transporter controls GSNO reductase and ethylene in Arabidopsis thaliana roots. Frontiers in Plant Science 9, 1325. doi:10.3389/fpls.2018.01325

García MJ, Lucena C, Romera FJ, Alcántara E, Pérez-Vicente R. 2010. Ethylene and nitric oxide involvement in the up-regulation of key genes related to iron acquisition and homeostasis in Arabidopsis. Journal of Experimental Botany 61, 3885-3899.

García MJ, Romera FJ, Stacey MG, Stacey G, Villar E, Alcántara E, Pérez-Vicente R. 2013. Shoot to root communication is necessary to control the expression of ironacquisition genes in Strategy I plants. Planta 237, 65-75.

García MJ, Suárez V, Romera FJ, Alcántara E, Pérez-Vicente R. 2011. A new model involving ethylene, nitric oxide and $\mathrm{Fe}$ to explain the regulation of $\mathrm{Fe}$-acquisition genes in Strategy I plants. Plant Physiology and Biochemistry 49, 537-544.

Garcia-Mata C, Gay R, Sokolovski S, Hills A, Lamattina L, Blatt MR. 2003. Nitric oxide regulates $\mathrm{K}^{+}$and $\mathrm{Cl}^{-}$channels in guard cells through a subset of abscisic acid-evoked signaling pathways. Proceedings of the National Academy of Sciences 100, 11116-11121.

Garcia-Mata C, Lamattina L. 2003. Abscisic acid, nitric oxide and stomatal closure - is nitrate reductase one of the missing links? Trends in Plant Science 8, 20-26.

Gaume A, Machler F, De Leon C, Narro L, Frossard E. 2001. Low-P tolerance by 
maize (Zea mays L.) genotypes: Significance of root growth, and organic acids and acid phosphatase root exudation. Plant Soil 228, 253-264.

Graziano M, Beligni MV, Lamattina L. 2002. Nitric oxide improves internal iron availability in plants. Plant Physiology 130, 1852-1859.

Graziano M, Lamattina L. 2007. Nitric oxide accumulation is required for molecular and physiological responses to iron deficiency in tomato roots. The Plant Journal 52, 949-960.

Gruber BD, Giehl RFH, Friedel S, von Wirén N. 2013. Plasticity of the Arabidopsis root system under nutrient deficiencies. Plant Physiology 163, 161-179.

Gupta KJ, Fernie AR, Kaiser WM, van Dongen JT. 2011. On the origins of nitric oxide. Trends in Plant Science 16, 160-168.

Halliwell B, Gutteridge JM. 1999. Free radicals in biology and medicine. Oxford: Oxford University Press.

Harberd NP, Belfield E, Yasumura Y. 2009. The angiosperm Gibberellin-GID1-DELLA growth regulatory mechanism: how an "inhibitor of an inhibitor" enables flexible response to fluctuating environments. The Plant Cell 21, 1328-1339.

Holford ICR. 1997. Soil phosphorus: its measurement, and its uptake by plants. Soil Research 35, 227-240.

Imran QM, Hussain A, Mun B-G, Lee SU, Asaf S, Ali MA, Lee I-J, Yun B-W. 2018. Transcriptome wide identification and characterization of NO-responsive WRKY transcription factors in Arabidopsis thaliana L. Environmental and Experimental Botany 148, 128-143.

Ishimaru Y, Suzuki M, Tsukamoto T, et al. 2006. Rice plants take up iron as an $\mathrm{Fe}^{3+}-$ phytosiderophore and as $\mathrm{Fe}^{2+}$. The Plant Journal 45, 335-346.

Jain P, Bhatla SC. 2018. Molecular mechanisms accompanying nitric oxide signalling through tyrosine nitration and S-nitrosylation of proteins in plants. Functional Plant Biology 45, 70-82.

Jasid S, Simontacchi M, Puntarulo S. 2008. Exposure to nitric oxide protects against oxidative damage but increases the labile iron pool in sorghum embryonic axes. Journal of Experimental Botany 59, 3953-3962.

Jeandroz S, Wipf D, Stuehr DJ, Lamattina L, Melkonian M, Tian Z, Zhu Y, Carpenter EJ, Wong GK, Wendehenne D. 2016. Occurrence, structure, and evolution of 
nitric oxide synthase-like proteins in the plant kingdom. Science Signaling 9. doi:10.1126/scisignal.aad4403

Jiang C, Gao X, Liao L, Harberd NP, Fu X. 2007. Phosphate starvation root architecture and anthocyanin accumulation responses are modulated by the gibberellin-DELLA signaling pathway in Arabidopsis. Plant Physiology 145, 1460-1470.

Jin CW, Du ST, Shamsi IH, Luo BF, Lin XY. 2011. NO synthase-generated NO acts downstream of auxin in regulating Fe-deficiency-induced root branching that enhances Fedeficiency tolerance in tomato plants. Journal of Experimental Botany 62, 3875-3884.

Jin CW, Du ST, Zhang YS, Lin XY, Tang CX. 2009. Differential regulatory role of nitric oxide in mediating nitrate reductase activity in roots of tomato (Solanum lycocarpum). Annals of Botany 104, 9-17.

Kant S. 2018. Understanding nitrate uptake, signaling and remobilisation for improving plant nitrogen use efficiency. Seminars in Cell \& Developmental Biology 74, 89-96.

Kellermeier F, Chardon F, Amtmann A. 2013. Natural variation of Arabidopsis root architecture reveals complementing adaptive strategies to potassium starvation. Plant Physiology 161, 1421-1432.

Kobayashi T, Nishizawa NK. 2012. Iron Uptake, Translocation, and regulation in higher plants. Annual Review of Plant Biology 63, 131-152.

Kolbert Z, Feigl G, Bordé Á, Molnár Á, Erdei L. 2017. Protein tyrosine nitration in plants: Present knowledge, computational prediction and future perspectives. Plant Physiology and Biochemistry 113, 56-63.

Lambers H, Cawthray GR, Giavalisco P, Kuo J, Laliberté E, Pearse SJ, Scheible WR, Stitt , Teste F y Turner BL. 2012. Proteaceae from severely phosphorus-impoverished soils extensively replace phospholipids with galactolipids and sulfolipids during leaf development to achieve a high photosynthetic phosphorus-use-efficiency. New Phytologist 196, 1098-1108.

Lambers H, Finnegan PM, Laliberté E, Pearse SJ, Ryan MH, Shane MW, Veneklaas EJ. 2011. Phosphorus nutrition of proteaceae in severely phosphorus-impoverished soils: are there lessons to be learned for future crops? Plant Physiology 156, 1058-1066.

Lambers H, Shane MW, Cramer MD, Pearse SJ, Veneklaas EJ. 2006. Root structure and functioning for efficient acquisition of phosphorus: Matching morphological and 
physiological raits. Annals of Botany 98, 693-713.

Laxalt AM, García-Mata C, Lamattina L. 2016. The dual role of nitric oxide in guard cells: promoting and attenuating the ABA and phospholipid-derived signals leading to the stomatal closure. Front. Plant Sci. 7, 476. doi: 10.3389/fpls.2016.00476

Li YS, Gao Y, Tian QY, Shi FL, Li LH, Zhang WH. 2011. Stimulation of root acid phosphatase by phosphorus deficiency is regulated by ethylene in Medicago falcata. Environmental and Experimental Botany, 71, 114-120.

Lillo C, Meyer C, Lea US, Provan F, Oltedal S. 2004. Mechanism and importance of post-translational regulation of nitrate reductase. Journal of Experimental Botany 55, 12751282.

Lindermayr C. 2018. Crosstalk between reactive oxygen species and nitric oxide in plants: Key role of S-nitrosoglutathione reductase. Free Radical Biology and Medicine 122, 110115.

Liu M, Liu XX, He XL, Liu LJ, Wu H, Tang CX, Zhang YS. 2017. Ethylene and nitric oxide interact to regulate the magnesium deficiency-induced root hair development in Arabidopsis. New Phytologist 213, 1242-1256.

Liu M, Zhang H, Fang X, Zhang Y, Jin C. 2018. Auxin acts downstream of ethylene and nitric oxide to regulate magnesium deficiency-induced root hair development in Arabidopsis thaliana. Plant \& Cell Physiology 59, 1452-1465.

Lombardo MC, Graziano M, Polacco JC, Lamattina L. 2006. Nitric oxide functions as a positive regulator of root hair development. Plant Signaling \& Behavior 1, 28-33.

López-Arredondo DL, Leyva-González MA, González-Morales SI, López-Bucio J, Herrera-Estrella L. 2014. Phosphate nutrition: Improving low-phosphate tolerance in crops. Annual Review of Plant Biology 65, 95-123.

López-Bucio J, Hernández-Abreu E, Sánchez-Calderón L, Nieto- Jacobo MF, Simpson J, Herrera-Estrella L. 2002. Phosphate availability alters architecture and causes changes in hormone sensitivity in the Arabidopsis root system. Plant Physiol. 129, 244256.

Lozano-Juste J, Colom-Moreno R, León J. 2011. In vivo protein tyrosine nitration in Arabidopsis thaliana. Journal of Experimental Botany 62, 3501-3517. 
Lozano-Juste J, León J. 2011. Nitric oxide regulates DELLA content and PIF expression to promote photomorphogenesis in Arabidopsis. Plant Physiology 156, 1410-23.

Lucena C, Waters BM, Romera FJ, García MJ, Morales M, Alcántara E, Pérez-

Vicente R. 2006. Ethylene could influence ferric reductase, iron transporter, and $\mathrm{H}^{+}$ATPase gene expression by affecting FER (or FER-like) gene activity. Journal of Experimental Botany 57, 4145-4154.

Ma JF, Ling H-Q. 2009. Iron for plants and humans. Plant Soil 325, 1-3.

Maathuis FJM. 2009. Physiological functions of mineral macronutrients. Current Opinion in Plant Biology 12, 250-258.

Manoli A, Begheldo M, Genre A, Lanfranco L, Trevisan S, Quaggiotti S. 2014. NO homeostasis is a key regulator of early nitrate perception and root elongation in maize. Journal of Experimental Botany 65, 185-200.

Marvasi M. 2017. Potential use and perspectives of nitric oxide donors in agriculture. Journal of the Science of Food and Agriculture 97, 1065-1072.

Martin M, Rodríguez Colman MJ, Gómez-Casati DF, Lamattina L, Zabaleta EJ. 2009. Nitric oxide accumulation is required to protect against iron-mediated oxidative stress in frataxin-deficient Arabidopsis plants. FEBS Letters 583, 542-548.

Meiser J, Lingam S, Bauer P. 2011. Posttranslational regulation of the iron deficiency Basic Helix-Loop-Helix transcription factor FIT is affected by iron and nitric oxide. Plant Physiology 157, 2154-2166.

Meng ZB, Chen LQ, Suo D, Li GX, Tang CX, Zheng SJ. 2012. Nitric oxide is the shared signalling molecule in phosphorus- and iron-deficiency-induced formation of cluster roots in white lupin (Lupinus albus). Annals of Botany 109, 1055-1064.

Mengel A, Ageeva A, Georgii E, Bernhardt J, Wu K, Durner J, Lindermayr C. 2017. Nitric oxide modulates histone acetylation at stress genes by inhibition of histone deacetylases. Plant Physiology 173, 1434-1452.

Moreau M, Lindermayr C, Durner J, Klessig DF. 2010. NO synthesis and signaling in plants - where do we stand? Physiologia Plantarum 138, 372-383

Moriconi JI, Buet A, Simontacchi M, Santa-María GE. 2012. Near-isogenic wheat lines carrying altered function alleles of the Rht-l genes exhibit differential responses to potassium deprivation. Plant Science 185-186, 199-207. 
Mur LAJ, Mandon J, Persijn S, Cristescu SM, Moshkov IE, Novikova GV, Hall MA, Harren FJM, Hebelstrup KH, Gupta KJ. 2013. Nitric oxide in plants: an assessment of the current state of knowledge. AoB Plants 5. doi:10.1093/aobpla/pls052

Murgia I, Delledonne M, Soave C. 2002. Nitric oxide mediates iron-induced ferritin accumulation in Arabidopsis. The Plant Journal 30, 521-528.

Nacry P, Canivenc G, Muller B, Azmi A, Onckelen HV, Rossignol M, Doumas P. 2005. A role for auxin redistribution in the responses of the root system architecture to phosphate starvation in Arabidopsis. Plant Physiology 138, 2061-2074.

Nikolic M, Pavlovic J. 2018. Plant responses to iron deficiency and toxicity and iron use efficiency in plants. In: Hossain MA, Kamiya T, Burritt DJ, Tran L-SP, Fujiwara T, eds. Plant Micronutrient Use Efficiency, Molecular and Genomic Perspectives in Crop Plants. Academic Press, 55-69.

Niu YF, Chai RS, Jin GL, Wang H, Tang CX, Zhang YS. 2013. Responses of root architecture development to low phosphorus availability: a review. Annals of Botany 112, 391-408.

O’Brien JA, Vega A, Bouguyon E, Krouk G, Gojon A, Coruzzi G, Gutiérrez RA. 2016. Nitrate transport, sensing, and responses in plants. Molecular Plant 9, 837-856.

Ortega-Galisteo AP, Rodríguez-Serrano M, Pazmiño DM, Gupta DK, Sandalio LM, Romero-Puertas MC. 2012. S-Nitrosylated proteins in pea (Pisum sativum L.) leaf peroxisomes: changes under abiotic stress. Journal of Experimental Botany 63, 2089-2103. Perazzolli M, Dominici P, Romero-Puertas MC, Zago E, Zeier J, Sonoda M, Lamb C, Delledonne M. 2004. Arabidopsis nonsymbiotic hemoglobin AHb1 modulates nitric oxide bioactivity. The Plant Cell 16, 2785-2794.

Perazzolli M, Romero-Puertas MC, Delledonne M. 2006. Modulation of nitric oxide bioactivity by plant haemoglobins. Journal of Experimental Botany 57, 479-488.

Plaxton WC, Tran HT. 2011. Metabolic adaptations of phosphate-starved plants. Plant Physiology 156, 1006-1015.

Rabe E, Lovatt CJ. 1986. Increased arginine biosynthesis during phosphorus deficiency. Plant Physiology 81, 774-779.

Radi R. 2004. Nitric oxide, oxidants, and protein tyrosine nitration. Proceedings of the National Academy of Sciences 101, 4003-4008. 
Raghothama KG. 1999. Phosphate acquisition. Annual Review of Plant Physiology and Plant Molecular Biology 50,665-693.

Raghothama KG, Karthikeyan AS. 2005. Phosphate acquisition. Plant and Soil 274, 3749.

Ramos-Artuso F, Galatro A, Buet A, Santa-María GE, Simontacchi M. 2018. Key acclimation responses to phosphorus deficiency in maize plants are influenced by exogenous nitric oxide. Journal of Plant Physiology 222, 51-58.

Ramos-Artuso F, Galatro A, Lima A, Batthyany C, Simontacchi M. 2019. Early events following phosphorus restriction involve changes in proteome and affects nitric oxide metabolism in soybean leaves. Environmental and Experimental Botany, doi.org/10.1016/j.envexpbot.2019.01.002

Roldan M, Dinh P, Leung S, McManus MT. 2013. Ethylene and the responses of plants to phosphate deficiency. AoB Plants. 5: plt013. doi: 10.1093/aobpla/plt013

Rosales EP, Iannone MF, Groppa MD, Benavides MP. 2011. Nitric oxide inhibits nitrate reductase activity in wheat leaves. Plant Physiology and Biochemistry 49, 124-30.

Rosales EP, Iannone MF, Groppa MD, Benavides MP. 2012. Polyamines modulate nitrate reductase activity in wheat leaves: involvement of nitric oxide. Amino Acids 42, 857-865.

Royo B, Moran JF, Ratcliffe RG, Gupta KJ. 2015. Nitric oxide induces the alternative oxidase pathway in Arabidopsis seedlings deprived of inorganic phosphate. Journal of Experimental Botany 66, 6273-6280.

Sánchez-Calderón L, López-Bucio J, Chacón-López A, Cruz-Ramírez A, NietoJacobo F, Dubrovsky JG, Herrera-Estrella L. 2005. Phosphate starvation induces a determinate developmental program in the roots of Arabidopsis thaliana. Plant \& Cell Physiology 46, 174-184.

Santa-María GE, Oliferuk S, Moriconi JI. 2018. KT-HAK-KUP transporters in major terrestrial photosynthetic organisms: A twenty years tale. Journal of Plant Physiology 226, 77-90.

Santolini J, André F, Jeandroz S, Wendehenne D. 2017. Nitric oxide synthase in plants: Where do we stand? Nitric Oxide 63, 30-38.

Sanz-Luque E, Ocaña-Calahorro F, Llamas Á, Galván A, Fernández E. 2013. Nitric 
oxide controls nitrate and ammonium assimilation in Chlamydomonas reinhardtii. Journal of Experimental Botany 64, 3373-3383.

Scuffi D, Alvarez C, Laspina N, Gotor C, Lamattina L, Garcia-Mata C. 2014. Hydrogen sulfide generated by L-cysteine desulfhydrase acts upstream of nitric oxide to modulate abscisic acid-dependent stomatal closure. Plant Physiology 166, 2065-2076.

Shabala S. 2017. Signalling by potassium: Another second messenger to add to the list? Journal of Experimental Botany 68, 4003-4007.

Shanmugam V, Wang Y-W, Tsednee M, Karunakaran K, Yeh K-C. 2015. Glutathione plays an essential role in nitric oxide-mediated iron-deficiency signaling and irondeficiency tolerance in Arabidopsis. The Plant Journal 84, 464-477.

Shen H, Chen J, Wang Z, Yang C, Sasaki T, Yamamoto Y, Matsumoto H, Yan X. 2006. Root plasma membrane $\mathrm{H}^{+}$-ATPase is involved in the adaptation of soybean to phosphorus starvation. Journal of Experimental Botany 57, 1353-1362.

Shen J, Yuan L, Zhang J, Li H, Bai Z, Chen X, Zhang W, Zhang F. 2011. Phosphorus dynamics: from soil to plant. Plant Physiology 156, 997-1005.

Simontacchi M, Buet A, Lamattina L, Puntarulo S. 2012. Exposure to nitric oxide increases the nitrosyl-iron complexes content in sorghum embryonic axes. Plant Science 183, 159-166.

Simontacchi M, Galatro A, Ramos-Artuso F, Santa-María GE. 2015. Plant survival in a changing environment: The role of nitric oxide in plant responses to abiotic stress. Frontiers in Plant Science 6, doi:10.3389/fpls.2015.00977

Sokolovski S, Blatt MR. 2004. Nitric oxide block of outward-rectifying $\mathrm{K}^{+}$channels indicates direct control by protein nitrosylation in guard cells. Plant Physiology 136, 42754284.

Song W, Xue R, Song Y, et al. 2018. Differential response of first-order lateral root elongation to low potassium involves nitric oxide in two tobacco cultivars. Journal of Plant Growth Regulation 37, 114-127.

Stepanova AN, Yun J, Likhacheva AV, Alonso JM. 2007. Multilevel interactions between ethylene and auxin in Arabidopsis roots. The Plant Cell 19, 2169-2185.

Sun H, Feng F, Liu J, Zhao Q. 2017. The interaction between auxin and nitric oxide regulates root growth in response to iron deficiency in rice. Frontiers in Plant Science 8, 
2169. doi:10.3389/fpls.2017.02169

Sun H, Li J, Song W, Tao J, Huang S, Chen S, Hou M, Xu G, Zhang Y. 2015. Nitric oxide generated by nitrate reductase increases nitrogen uptake capacity by inducing lateral root formation and inorganic nitrogen uptake under partial nitrate nutrition in rice. Journal of Experimental Botany 66, 2449-2459.

Terrile MC, París R, Calderón-Villalobos LIA, Iglesias MJ, Lamattina L, Estelle M, Casalongué CA. 2012. Nitric oxide influences auxin signaling through $S$-nitrosylation of the Arabidopsis TRANSPORT INHIBITOR RESPONSE 1 auxin receptor. The Plant Journal 70, 492-500.

Trevisan S, Manoli A, Begheldo M, Nonis A, Enna M, Vaccaro S, Caporale G, Ruperti B, Quaggiotti S. 2011. Transcriptome analysis reveals coordinated spatiotemporal regulation of hemoglobin and nitrate reductase in response to nitrate in maize roots. New Phytologist 192, 338-352.

Trevisan S, Manoli A, Quaggiotti S. 2014. NO signaling is a key component of the root growth response to nitrate in Zea mays L. Plant Signaling \& Behavior 9,(3):e28290. Trevisan S, Manoli A, Ravazzolo L, Botton A, Pivato M, Masi A, Quaggiotti S. 2015. Nitrate sensing by the maize root apex transition zone: a merged transcriptomic and proteomic survey. Journal of Experimental Botany 66, 3699-3715.

Ullrich-Eberius CI, Novacky A, van Bel AJE. 1984. Phosphate uptake in Lemna gibba G1: Energetics and kinetics. Planta 161, 46-52.

Vance CP, Uhde-Stone C, Allan DL. 2003. Phosphorus acquisition and use: critical adaptations by plants for securing a nonrenewable resource. New Phytologist 157, 423447.

Véry A-A, Nieves-Cordones M, Daly M, Khan I, Fizames C, Sentenac H. 2014. Molecular biology of $\mathrm{K}^{+}$transport across the plant cell membrane: what do we learn from comparison between plant species? Journal of Plant Physiology 171, 748 -769.

Wang BL, Tang XY, Cheng LY, et al. 2010. Nitric oxide is involved in phosphorus deficiency-induced cluster-root development and citrate exudation in white lupin. New Phytologist 187, 1112-1123.

Wang H, Liang X, Wan Q, Wang X, Bi Y. 2009. Ethylene and nitric oxide are involved in maintaining ion homeostasis in Arabidopsis callus under salt stress. Planta 230, 293-307. 
Wang Y-Y, Hsu P-K, Tsay Y-F. 2012. Uptake, allocation and signaling of nitrate. Trends in Plant Science 17, 458-467.

Wu AP, Gong L, Chen X, Wang JX. 2014. Interactions between nitric oxide, gibberellic acid, and phosphorus regulate primary root growth in Arabidopsis. Biologia Plantarum 58, 335-340.

Xia J, Kong D, Xue S, et al. 2014. Nitric oxide negatively regulates AKT1-mediated potassium uptake through modulating vitamin B6 homeostasis in Arabidopsis. Proceedings of the National Academy of Sciences 111, 16196-201.

Xu J, Yin H, Li Y, Liu X. 2010. Nitric oxide is associated with long-term zinc tolerance in Solanum nigrum. Plant Physiology 154, 1319-1334.

Yun B-W, Feechan A, Yin M, et al. 2011. S-nitrosylation of NADPH oxidase regulates cell death in plant immunity. Nature 478, 264-268.

Zandonadi DB, Santos MP, Dobbss LB, Olivares FL, Canellas LP, Binzel ML, Okorokova-Façanha AL, Façanha AR. 2010. Nitric oxide mediates humic acids-induced root development and plasma membrane $\mathrm{H}^{+}$-ATPase activation. Planta 231, 1025-1036.

Zhang H, Jennings A, Barlow PW, Forde BG. 1999. Dual pathways for regulation of root branching by nitrate. Proceedings of the National Academy of Sciences 96, 65296534.

Zhang L, Li G, Wang M, Di D, Sun L, Kronzucker HJ, Shi W. 2018. Excess iron stress reduces root tip zone growth through nitric oxide-mediated repression of potassium homeostasis in Arabidopsis. New Phytologist 219, 259-274.

Zhang Z, Liao H, Lucas WJ. 2014. Molecular mechanisms underlying phosphate sensing, signaling, and adaptation in plants. Journal of Integrative Plant Biology 56, 192-220.

Zhao L, Zhang F, Guo J, Yang Y, Li B, Zhang L. 2004. Nitric oxide functions as a signal in salt resistance in the calluses from two ecotypes of Reed. Plant Physiology 134, 849-857.

Zhu CQ, Zhang JH, Zhu LF, et al. 2018. $\mathrm{NH}_{4}{ }^{+}$facilitates iron reutilization in the cell walls of rice (Oryza sativa) roots under iron-deficiency conditions. Environmental and Experimental Botany 151, 21-31.

Zhu CQ, Zhu XF, Hu AY, Wang C, Wang B, Dong XY, Shen R-F. 2016. Differential effects of nitrogen forms on cell wall phosphorus remobilization are mediated by nitric 
oxide, pectin content, and phosphate transporter expression. Plant Physiology 171, 14071417.

Zhu XF, Zhu CQ, Wang C, Dong XY, Shen RF. 2017. Nitric oxide acts upstream of ethylene in cell wall phosphorus reutilization in phosphorus-deficient rice. Journal of Experimental Botany 68, 753-760.

Zhu XF, Wang B, Song WF, Zheng SJ, Shen RF. 2016. Putrescine alleviates iron deficiency via NO-dependent reutilization of root cell-wall Fe in Arabidopsis. Plant Physiology 170, 558-67.

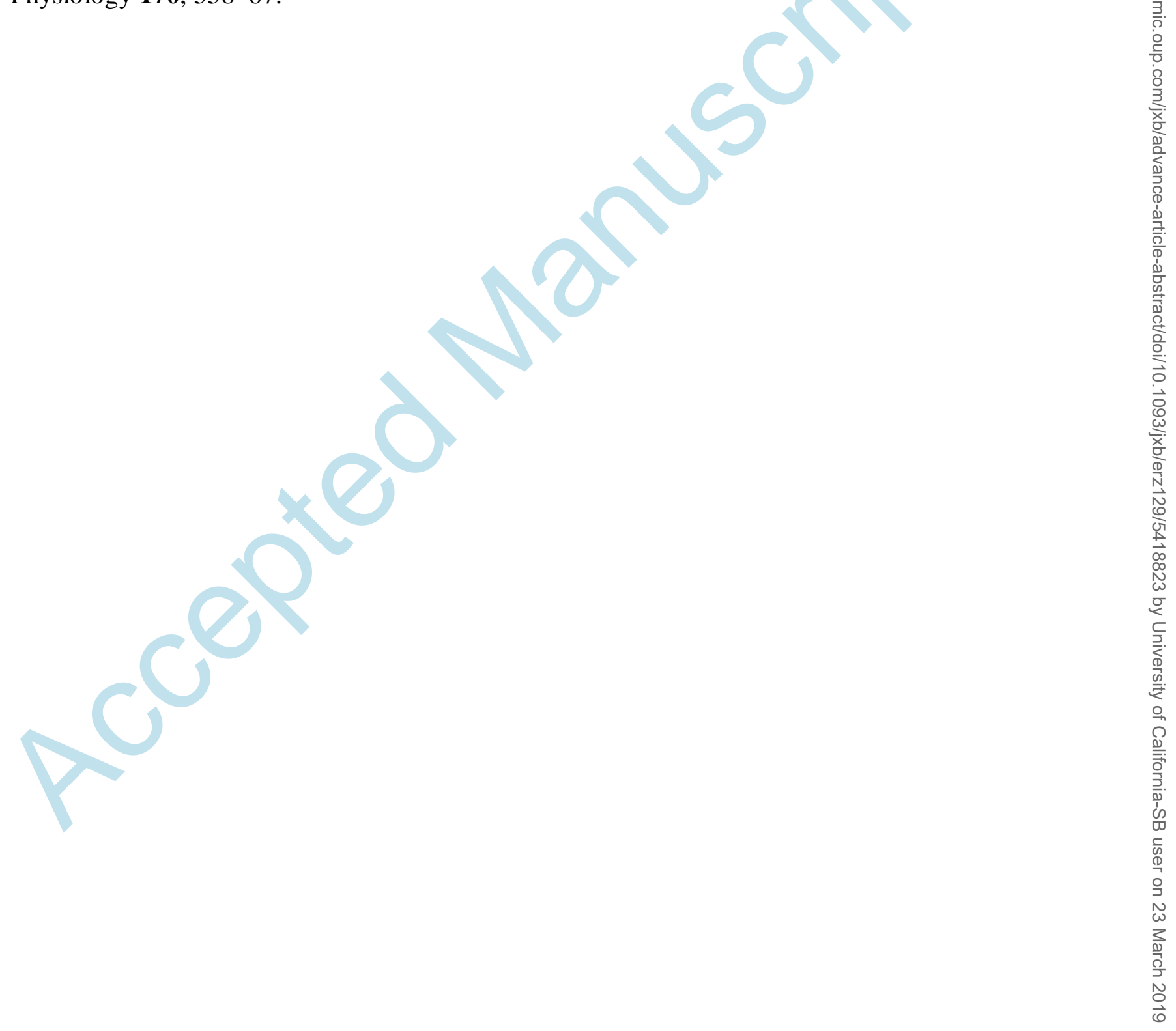


Table 1. Modulation of NR activity by NO level under different nitrogen supply

\begin{tabular}{|c|c|c|c|c|c|c|}
\hline Species & Source of nitrogen & NO donor (or mutant) & Time & Tissues & NR activity & References \\
\hline $\begin{array}{l}\text { Chinese } \\
\text { cabbage pakchoi } \\
\text { (Brassica } \\
\text { chinensis L.) }\end{array}$ & $\begin{array}{l}1 \mathrm{mM} \mathrm{KNO}_{3} \text { and } \\
0.25 \mathrm{mM}\left(\mathrm{NH}_{4}\right)_{2} \mathrm{SO}_{4}\end{array}$ & $\begin{array}{l}\text { Up to } 100 \mu \mathrm{M} \text { of SNP } \\
\text { and DEA/NONOate (in } \\
\text { the nutrient solution) }\end{array}$ & $3 \mathrm{~h}$ & Roots & $\begin{array}{l}\uparrow 205 \% \text { at } 40 \mu \mathrm{M} \text { SNP } \\
\uparrow 282 \% \text { at } 80 \mu \mathrm{M} \\
\text { DEA/NONOate }\end{array}$ & Du et al., 2008 离 \\
\hline $\begin{array}{l}\text { Tomato } \\
\text { (Solanum } \\
\text { lycocarpum) }\end{array}$ & $\begin{array}{l}0.250 \mathrm{mM}\left(\mathrm{NH}_{4}\right)_{2} \mathrm{SO}_{4} \\
\text { and two different } \\
\text { levels of } \mathrm{NO}_{3}^{-}: 0.5 \\
\mathrm{mM} \text { (low } \mathrm{NO}_{3}^{-} \\
\text {supply) and } 5 \mathrm{mM} \\
\text { (high } \mathrm{NO}_{3}^{-} \text {supply) }\end{array}$ & $\begin{array}{l}\text { SNP and } \\
\text { DEA/NONOate, up to } \\
10 \mu \mathrm{M} \text { (in the nutrient } \\
\text { solution) }\end{array}$ & $3 \mathrm{~h}$ & Roots & $\begin{array}{l}\uparrow \text { at low } \mathrm{NO}_{3}^{-} \text {supply up to } \\
2 \mu \mathrm{M} \text { SNP and } 10 \mu \mathrm{M} \\
\text { DEA/NONOate } \\
\downarrow \text { at high } \mathrm{NO}_{3}^{-} \text {supply up } \\
\text { to } 10 \mu \mathrm{M} \text { of both NO } \\
\text { donors }\end{array}$ & Jin et al., 2009丮 \\
\hline $\begin{array}{l}\text { Wheat (Triticum } \\
\text { aestivum L.) }\end{array}$ & 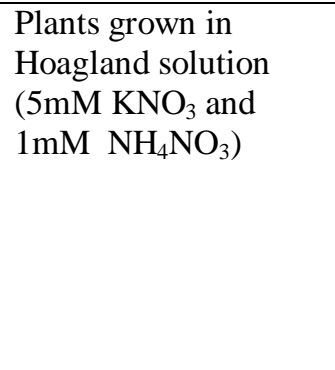 & $\begin{array}{l}\text { Up to } 500 \mu \mathrm{M} \text { SNP or } \\
\text { GSNO } \\
\text { (in distilled water) } \\
\text { Leaf segments in flasks } \\
\text { with the NO donors } \\
\text { under continuous light }\end{array}$ & $\begin{array}{l}3 \text { or } \\
21 \mathrm{~h}\end{array}$ & $\begin{array}{l}\text { Leaf } \\
\text { segments }\end{array}$ & $\begin{array}{l}\downarrow 45 \% \text { and } \downarrow 90 \% \text { on } \\
\text { average, at all incubation } \\
\text { times with } 10 \text { and } 500 \mu \mathrm{M} \\
\text { SNP respectively } \\
\downarrow 18 \% \text { with } 10 \text { or } 100 \mu \mathrm{M} \\
\text { GSNO, and } 26 \% \text { with } 500 \\
\mu \mathrm{M} \text { for } 3 \mathrm{~h} \\
\uparrow 27 \% \text { after } 21 \text { h with } 500 \\
\mu \mathrm{M} \text { GSNO }\end{array}$ & $\begin{array}{ll}\text { Rosales } \text { et al., } \\
2011\end{array}$ \\
\hline $\begin{array}{l}\text { Wheat (Triticum } \\
\text { aestivum, } \\
\text { cvs Spitfire and } \\
\text { Westonia }^{l}\end{array}$ & $\begin{array}{l}\text { Nutrient solution } \\
\text { similar to Hoagland } \\
\text { and irrigated with N- } \\
\text { free nutrient solution } \\
\text { for one week }\end{array}$ & $\begin{array}{l}\text { Up to } 100 \mu \mathrm{M} \text { of SNP } \\
\text { under different low } \\
(4 \mathrm{mM}) \text { or high ( } 40 \\
\mathrm{mM}) \mathrm{N} \text { supply as: } \\
\mathrm{KNO}_{3}, \mathrm{NH}_{4} \mathrm{Cl} \text { or } \\
\mathrm{NH}_{4} \mathrm{NO}_{3}\end{array}$ & $\begin{array}{l}3 \\
\text { days }\end{array}$ & Leaf tissues & $\begin{array}{l}\uparrow \text { Under low } \mathrm{NO}_{3}{ }^{-} \text {or } \mathrm{NH}_{4}{ }^{+} \\
\text {in both cultivars, and in } \\
\text { low } \mathrm{NH}_{4} \mathrm{NO}_{3} \text { in Spitfire } \\
\text { cultivar } \\
\downarrow \text { Under high } \mathrm{NO}_{3}^{-} \text {, but } \uparrow \\
\text { in high } \mathrm{NH}_{4} \mathrm{NO}_{3} \text { in Spitfire } \\
\text { cultivar }\end{array}$ & $\begin{array}{ll}\text { Balotf } \text { et al., } \\
2018\end{array}$ \\
\hline $\begin{array}{l}\text { Chlamydomona } \\
\text { s reinhardtii }\end{array}$ & $\begin{array}{l}\text { Cells grown in } 8 \mathrm{mM} \\
\text { amonium medium } \\
\text { and then induced in } 4 \\
\mathrm{mM} \mathrm{NO}{ }_{3}^{-} \text {medium } \\
\text { for } 3 \mathrm{~h}\end{array}$ & $\begin{array}{l}20 \mu \mathrm{M} \\
\text { DEA/NONOate, or } 50 \\
\text { and } 100 \mu \mathrm{M} \text { GSNO } \\
\text { (continuous ligth) }\end{array}$ & $\begin{array}{l}\text { Up to } \\
60 \\
\text { min }\end{array}$ & Cells & $\begin{array}{l}\downarrow 60 \% \text { after } 10 \text { and } 20 \text { min } \\
\text { with DEA-NONOate and } \\
\downarrow \text { about } 60 \% \text { after } \\
40 \text { min with GSNO }\end{array}$ & 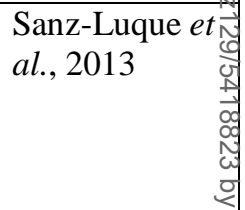 \\
\hline $\begin{array}{l}\text { Macroalga } \\
\text { Gracilaria } \\
\text { chilensis }\end{array}$ & $\begin{array}{l}\text { Seawater enriched } \\
\text { with } 100 \% \text { von } \\
\text { Stosch medium }(0.5 \\
\left.\mathrm{mM} \mathrm{NaNO}_{3}\right)\end{array}$ & $1 \mathrm{mM} \mathrm{SNP}$ & $2 \mathrm{~h}$ & $\begin{array}{l}\text { Unbranched } \\
\text { tips }(2 \mathrm{~cm})\end{array}$ & $\downarrow 99.98 \%$ & 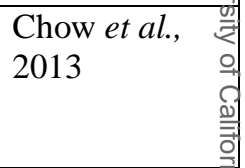 \\
\hline $\begin{array}{l}\text { Arabidopsis } \\
\text { thaliana }\end{array}$ & $\begin{array}{l}\text { Modified Murashige-- } \\
\text { Skoog nutrient } \\
\text { solution } \\
\text { Nitrate (about } 39,3 \\
\text { mM) composed of } \\
\text { half } \mathrm{KNO}_{3} \text { and half } \\
\mathrm{NH}_{4} \mathrm{NO}_{3}\end{array}$ & $\begin{array}{l}\text { Columbia-0 WT and } \\
\text { the mutants gsnorl and } \\
\text { nox } 1^{2}\end{array}$ & - & Leaf extracts & $\begin{array}{l}\downarrow \text { in } \text { gsnorl mutant } \\
\text { noxl mutant did not } \\
\text { exhibit altered NR activity }\end{array}$ & $\begin{array}{ll}\text { Frungillo et } & = \\
\text { al., } 2014 & \bar{u} \\
\text { in }\end{array}$ \\
\hline
\end{tabular}

DEA/NONOate, diethylamine NONOate; SNP, sodium nitroprusside; GSNO, S-nitrosoglutathion 


\section{Figure legends}

Fig. 1. NO mediated responses affecting nitrogen uptake and assimilation.

Changes in nitrogen supply may enhance NR activity (or expression) leading to NO accumulation that triggers root growth and the modulation of $\mathrm{NH}_{4}{ }^{+}$and $\mathrm{NO}_{3}{ }^{-}$transporters. However, other sources of NO generation may enhance NO levels. NO may control its bioavailability through the modulation of NR activity, and S-nitrosoglutathione (GSNO) levels due to GSNO reductase 1 (GSNOR1) inhibition and GSNO synthesis. Nonsymbiotic haemoglobins (nsHb) may also regulate NO steady state. 1- Sun et al., 2015; 2Manoli et al., 2014; 3- See data in Table 1; 4- Frungillo et al., 2014; 5-Perazzolli et al., 2004; 6- Sanz-Luque et al., 2013; 7- Lindermayr et al., 2018. Arrows show induction and blocked lines show inhibition.

Fig. 2. Low P-induced responses in plants mediated by NO and its interaction with hormones.

Low $\mathrm{P}$ in soils induces NO synthesis in plants (for details see the text). NO accumulation was related to enhanced acid phosphatase (AP) release and P-uptake in roots, increased organic acid (OA) exudation and $\mathrm{H}^{+}$release to the rhizosphere. NO interaction with hormones participates in root morphological changes. NO acts upstream of ethylene leading to cell wall composition changes and enhanced $\mathrm{P}$ remobilization and translocation to shoots through increased $\mathrm{P}$ transporter expression. Ethylene is also involved in the modulation of $\mathrm{AP}$ activity, P-uptake and OA exudation in response to low $\mathrm{P}$ levels. Low $\mathrm{P}$ and $\mathrm{NO}$ elicit auxin accumulation that was also associated with $\mathrm{H}^{+}$release. $\mathrm{NO}$ also inducts alternative oxidase (AOX) activity that allows metabolic flexibility. 1- Wang et al., 2010; 2- Zhu CQ et al., 2016; 3- Zhu et al., 2017; 4- Ramos-Artuso et al., 2018; 5-Zandonadi et al., 2010; 6Shen et al., 2006; 7- Correa-Aragunde et al., 2015; 8- Royo et al., 2015; 9- Roldan et al., 2013; 10- Li et al., 2011. Arrows show induction and blocked lines inhibition.

Fig. 3. Low $\mathrm{K}^{+}$induced responses in plants mediated by NO.

It was reported that in tobacco plants susceptible to $\mathrm{K}^{+}$restriction, $\mathrm{NO}$ increased in roots under $\mathrm{K}^{+}$-starvation, leading to root morphological changes. In plants exposed to excess $\mathrm{Fe}$, $\mathrm{NO}$ induce $\mathrm{K}^{+}$loss via nonselective cation channels (NSCCs). NO also mediates $\mathrm{K}^{+}$ homeostasis by the negative regulation of $\mathrm{K}^{+}$uptake and inactivates the $\mathrm{K}^{+}$inward rectifying channel $\left(I_{\mathrm{K}}\right.$, in $)$. Outward rectifying channel $\left(I_{\mathrm{K}}\right.$, out $)$ is inhibited through $\mathrm{S}$ nitrosation. In guard cells, the production of $\mathrm{NO}$ is required for ABA-induced stomatal closure. In addition, there is an attenuating effect of NO breaking the ABA stimulus by the inhibition and degradation of the ABA receptor through the nitration of Tyr residues. 1Song et al., 2018; 2- Xia et al., 2014; 3- Garcia-Mata and Lamattina, 2003; 4- Garcia-Mata et al., 2003; 5- Zhang et al., 2018; 6- Laxalt et al., 2016; 7- Chen et al., 2016; 8- Sokolovski and Blatt, 2004. Arrows show induction and blocked lines inhibition. 
Fig. 4. Low Fe-induced responses mediated by NO and proposed model for low Feinduced responses in strategy I plants mediated by NO-phytohormone interaction.

Panel A. Low Fe in soil promotes NO synthesis through NR and Arg-dependent via. NO accumulation elicits Fe-acquisition responses. Strategy I consists in FRO and IRT expression and $\mathrm{H}^{+}$release to rhizosphere through $\mathrm{H}^{+}$-ATPase pump expression. An unknown signal from Fe-sufficient shoots is sent to roots and inhibits Strategy I responses, this signal is absent in low Fe conditions. It was also reported that NO triggers the expression of YSL-like Fe-transporter in rice, a plant that employs Strategy II. Panel B. In shoots, low Fe impairs chlorophyll synthesis leading to leaf chlorosis which is reverted by NO, possibly through the formation of mononitrosyl- (MNIC) and dinitrosyl-Fe complexes (DNIC) which contribute to labile iron pool (LIP). More studies are required to confirm this hypothesis. Panel C. Proposed model for NO-phytohormone interaction in low Fe-induced responses in Strategy I plants. Low Fe promotes auxins increase that acts upstream to NO. Auxins are modulated through NO and NO-triggered ethylene accumulation. In turn, ethylene elicits FER/FIT transcription factor which, in turn, elicits Strategy I Fe-acquisition responses. Ethylene is also able to induct NO accumulation. NO interaction with auxins participates in root morphological changes and Fe-acquisition induction. 1- Graziano and Lamattina, 2007; 2- Chen et al., 2010; 3- Jin et al., 2011; 4- García et al., 2018; 5- Sun et al., 2017; 6- Zhu et al., 2018; 7- Simontacchi et al., 2012; 8- García et al., 2011; 9- Terrile et al., 2012; 10-Stepanova et al., 2007; 11- García et al., 2010. Arrows show induction and blocked lines inhibition, dotted line stands for proposed mechanisms.

Fig. 5. Common mechanisms involving NO participation under micro and macronutrient scarcity. Low nutrient availability promotes NO accumulation. NO leads to plant acclimation to nutrient scarcity through PTM to proteins. For some elements, it was reported that $\mathrm{NO}$ leads to auxins and ethylene accumulation that elicits nutrient acquisition and reutilization responses. Ethylene and auxins are also able to induct NO accumulation. NO interaction with auxins and ethylene participates in root morphological changes and nutrient acquisition induction. Arrows show induction and blocked lines inhibition. 


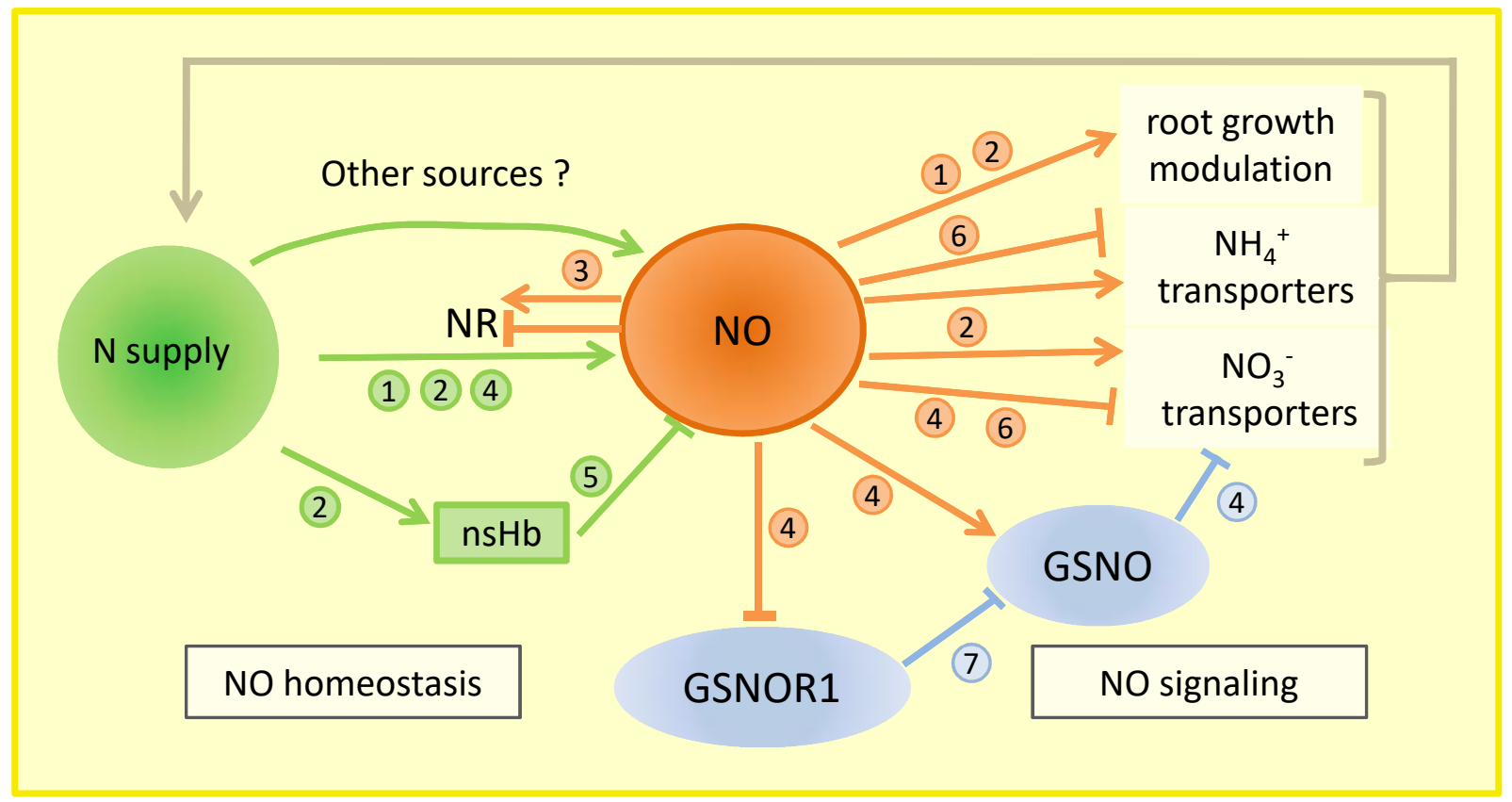

Figure 1 


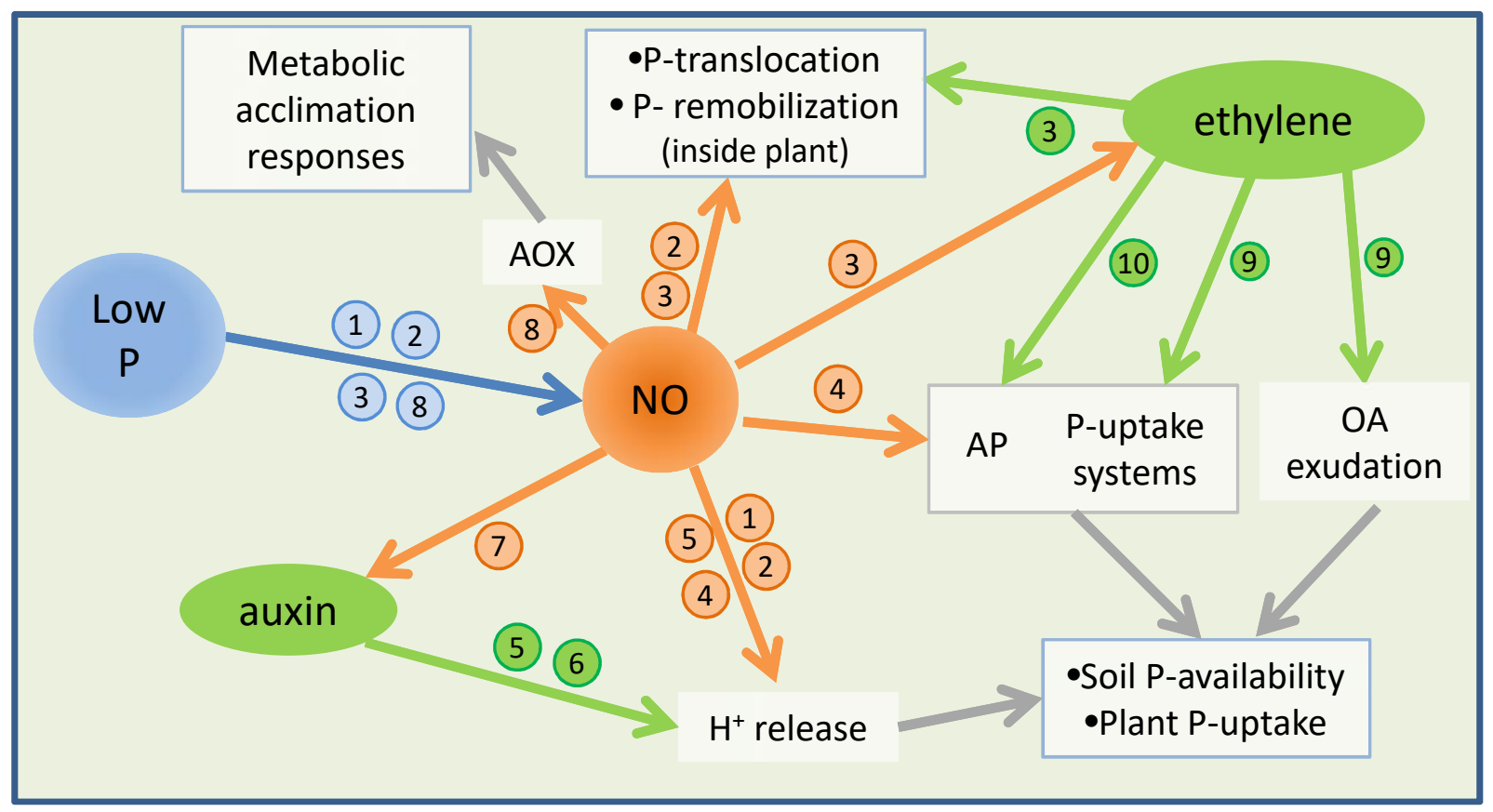

Figure 2 


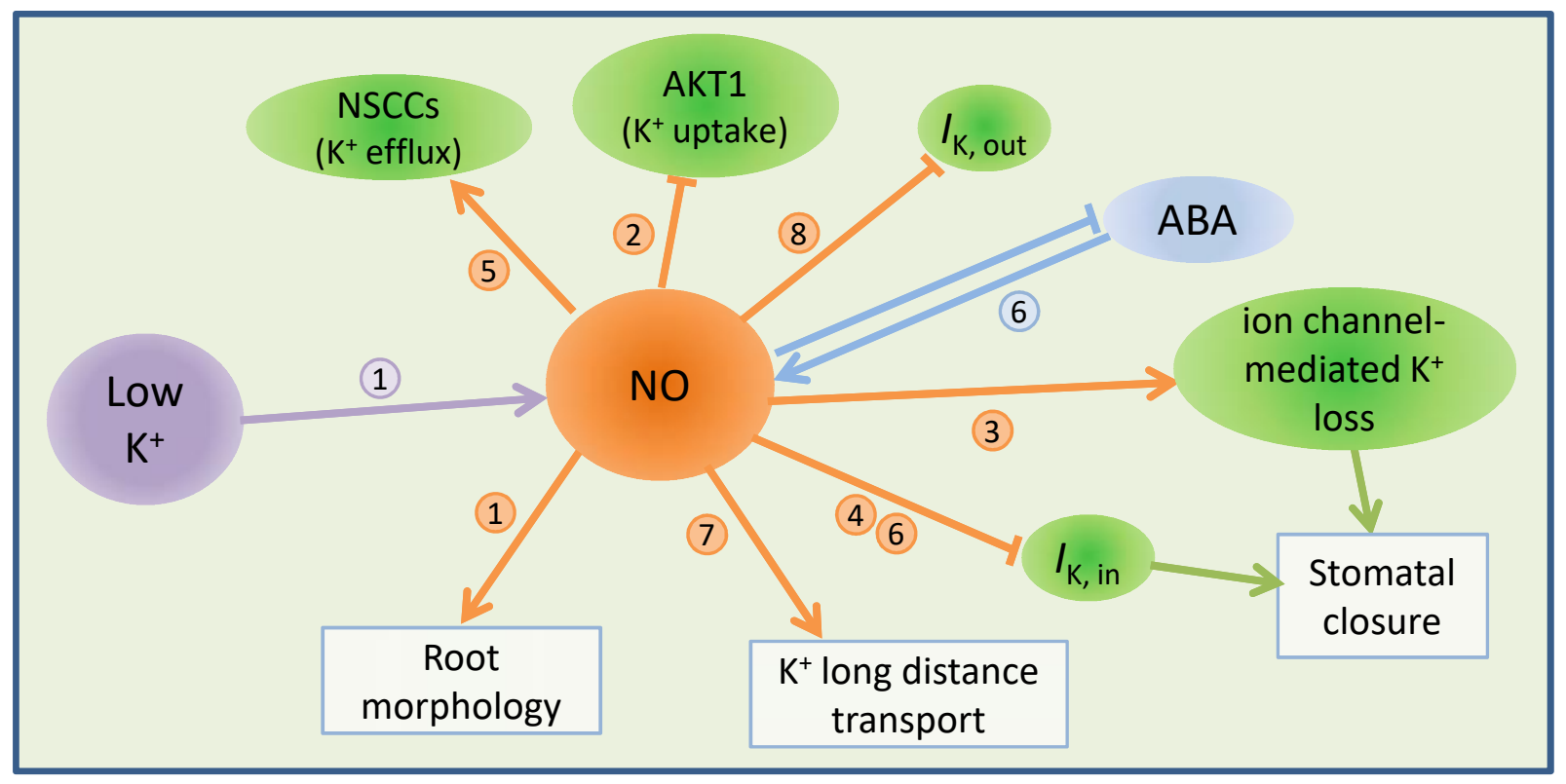

Figure 3 


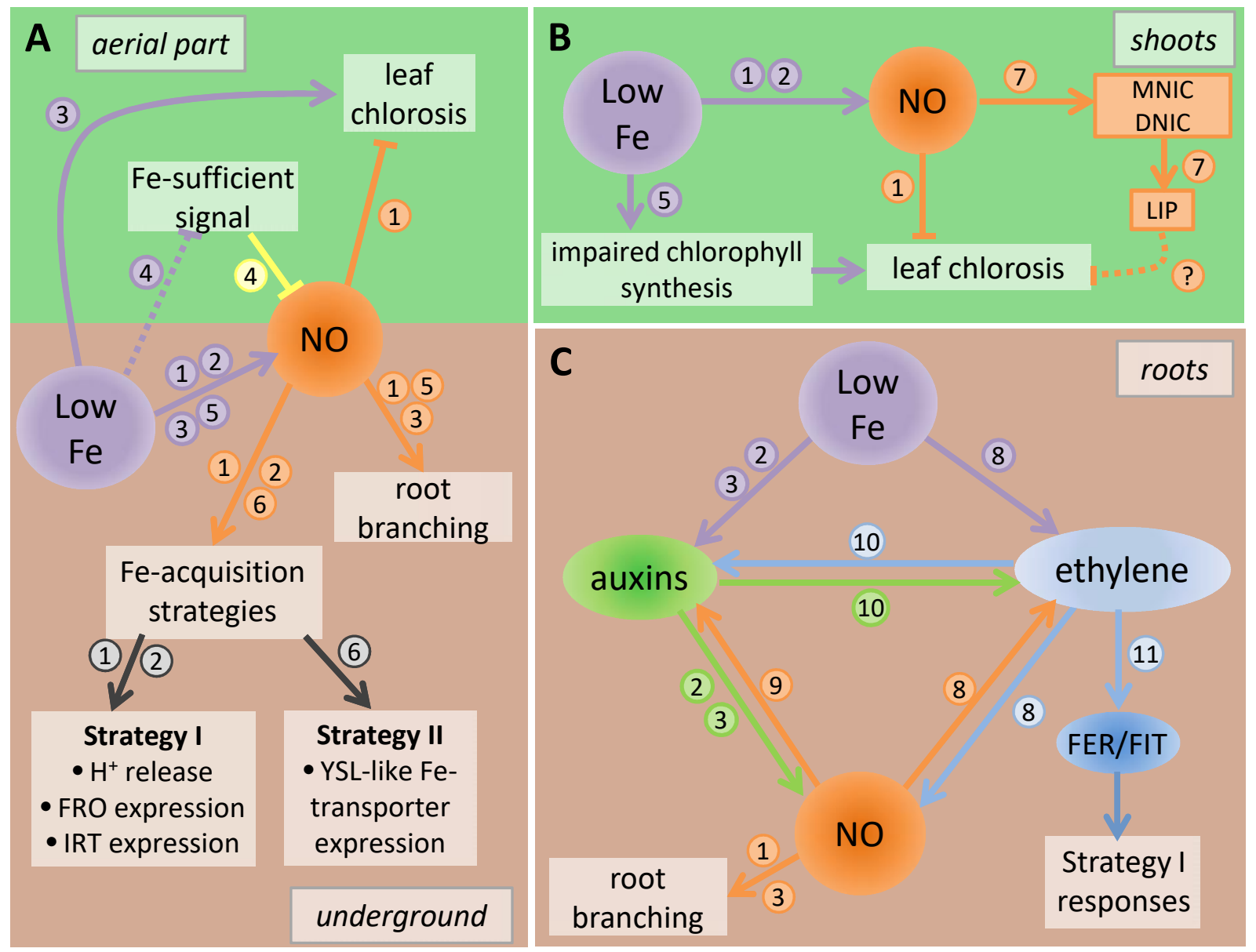

Figure 4 


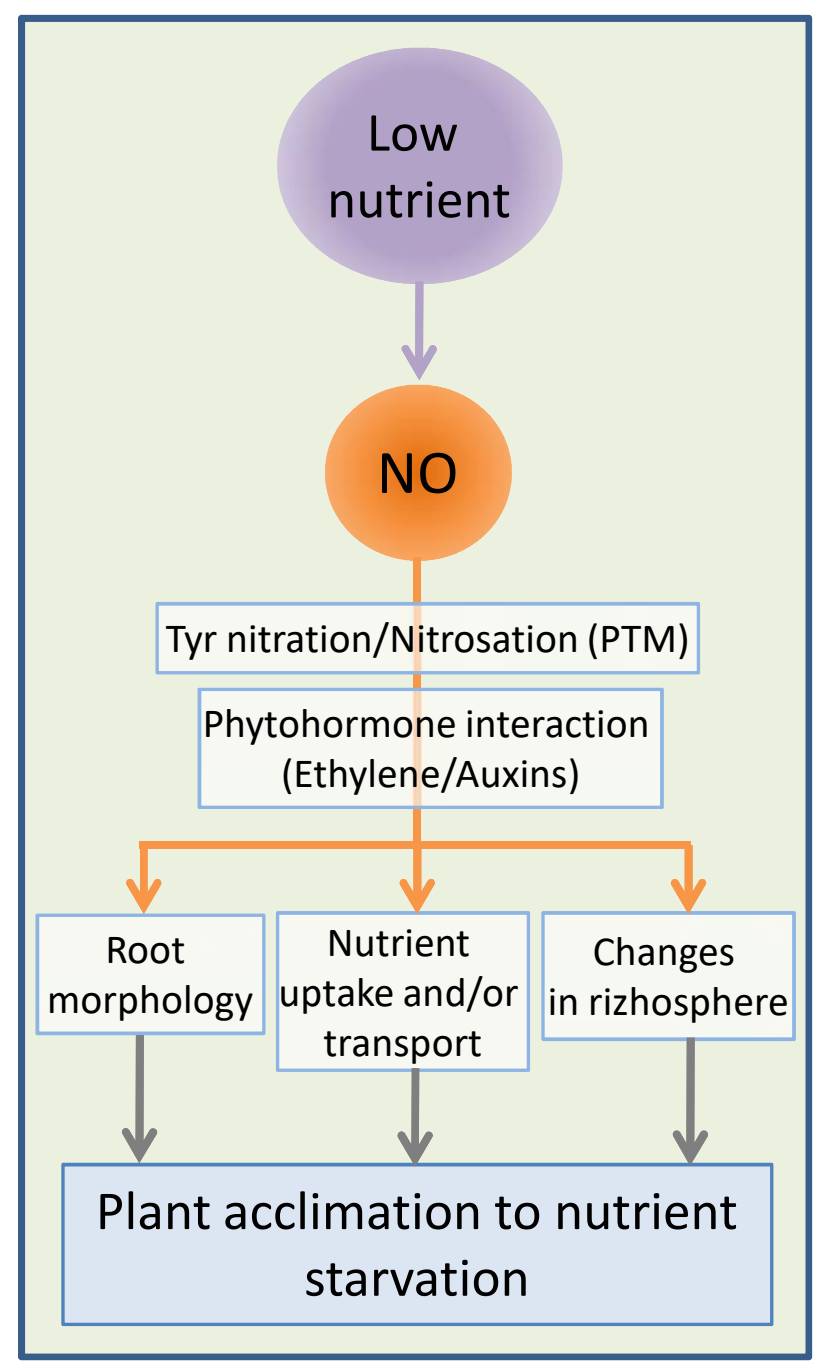

Figure 5 